
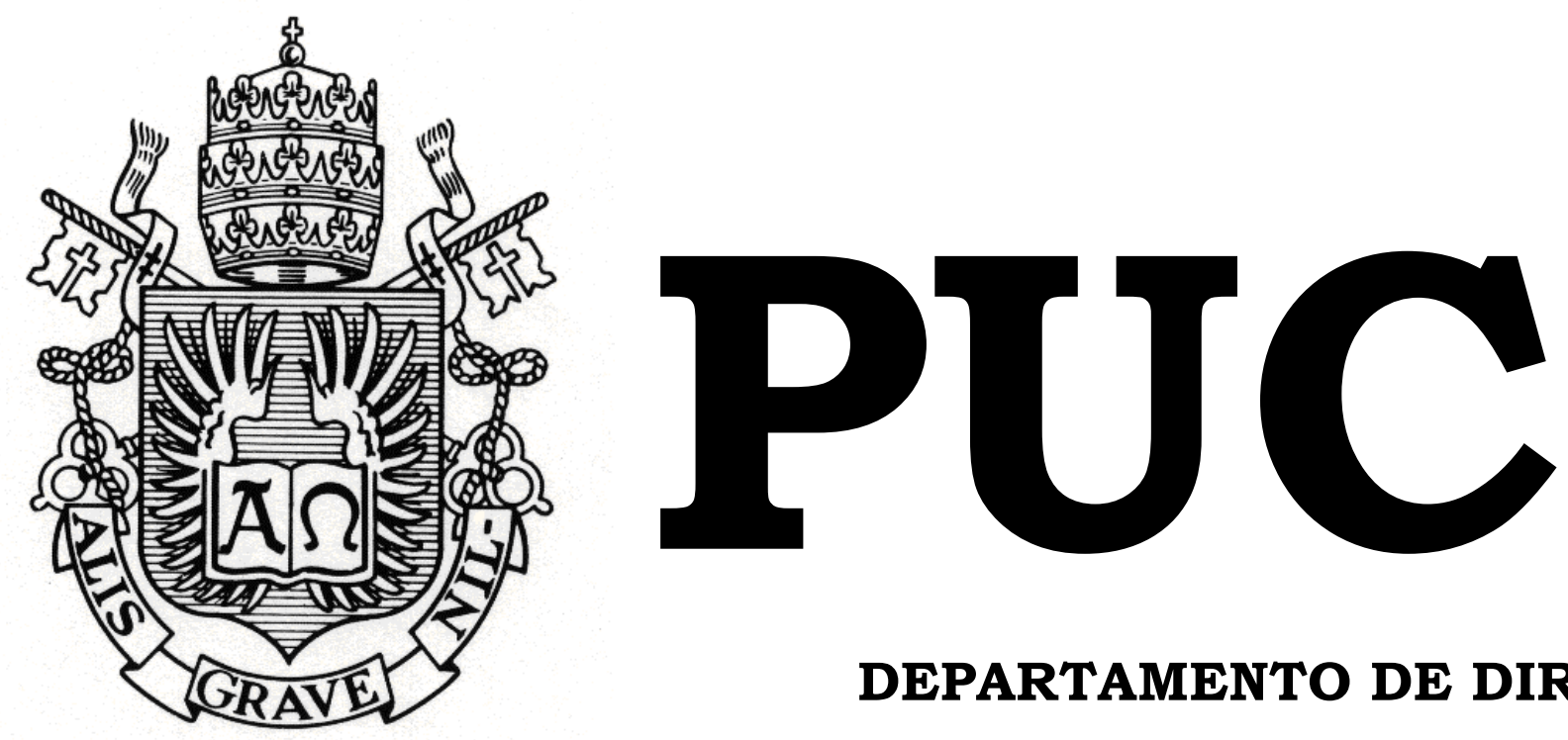

\title{
OS NOVOS TIPOS DE FAMÍLIA: UM ESTUDO SOBRE A UNIÃO HOMOAFETIVA
}

\author{
por
}

DANIEL BENJÓ

ORIENTADORA: ANA PAULA SANTORO PIRES DE CARVALHO ALMEIDA

2013.1

PONTIFÍCIA UNIVERSIDADE CATÓLICA DO RIO DE JANEIRO

RUA MARQUÊS DE SÃO VICENTE, 225 - CEP 22453-900

RIO DE JANEIRO - BRASIL 


\title{
OS NOVOS TIPOS DE FAMÍLIA: UM ESTUDO SOBRE A UNIÃO HOMOAFETIVA
}

\author{
por \\ DANIEL BENJÓ
}

Monografia apresentada ao

Departamento de Direito da

Pontifícia Universidade Católica do Rio de Janeiro (PUC-Rio) para a obtenção do Título de Bacharel em Direito.

Orientadora: Ana Paula Santoro Pires de Carvalho Almeida 


\section{RESUMO}

O presente trabalho monográfico visa o estudo do reconhecimento jurídico das uniões homoafetivas e todos os efeitos decorrentes da mesma. Inicialmente, faz-se um breve estudo sobre as mutações do conceito de família ao longo da história em importantes épocas que marcaram e influenciaram claramente a cultura e forma de pensar contemporânea, passando a vista pela influencia externa que sempre prosperou ao delimitar o que é família perante a sociedade, seja pela forma de governo, religião ou outros fatores. Mais adiante, o estudo busca o conceito e a importância do afeto para a caracterização da família no mundo atual, e analisa a questão da união homoafetiva desde antes do histórico julgado da ADI 4277, passando pela análise do próprio, até as discussões e dúvidas geradas após o mesmo assim como a possibilidade do casamento civil entre pessoas do mesmo sexo.

\section{PALAVRAS-CHAVE}

União homoafetiva. União estável. Família. Interpretação extensiva do artigo 226, $\S 3^{\circ}$ da Constituição Federal e do artigo 1.723 do Código Civil. ADI 4277. ADPF 132. Casamento Civil entre pessoas do mesmo sexo. Resolução CNJ nº 175. 


\section{SUMÁRIO}

$\begin{array}{ll}\text { INTRODUÇÃO } & 05\end{array}$

Capítulo 1

EVOLUÇÃO HISTÓRICA DO CONCEITO DE FAMÍLIA 08

1.1 - A Família Na Roma Antiga $\quad 08$

1.2 - A Família no Direito Canônico $\quad 09$

1.3 - A Família nas Constituições brasileiras pré 1988

1.4 - Inovações trazidas pela constituição de 1988

Capítulo 2

O CARÁTER AFETIVO 16

2.1 - Conceito de Afeto $\quad 16$

2.2 - O Princípio da Afetividade nas Relações Homoafetivas 18

Capítulo 3

A UNIÃO HOMOAFETIVA 21

3.1 - O projeto de Lei 2.285/2007 21

3.2 - Jurisprudência pré ADI 4277

3.2 .1 - Jurisprudência Favorável ao Reconhecimento da União
Homoafetiva

3.2.2 - Jurisprudência Contrária ao Reconhecimento da União Homoafetiva 28

3.3 - A ADI $4277 \quad 32$

3.3.1 - Breve Resumo

3.3.2 - O Voto do Ilustríssimo Ministro Ayres Britto 33

3.4 - Possibilidade do Casamento Civil entre Homossexuais 39

3.4.1 - A Controvérsia 39

3.4.2 - Argumentos Favoráveis $\quad 47$

3.5 - A Resolução CNJ no 175 e seu Recebimento 48

CONCLUSÃO $\quad 56$

$\begin{array}{ll}\text { BIBLIOGRAFIA } & 58\end{array}$ 


\section{Lista de Abreviações e Símbolos utilizados}

STF - Supremo Tribunal Federal

STJ - Superior Tribunal de Justiça

TJRJ - Tribunal de Justiça do Estado do Rio de Janeiro

TJRS - Tribunal de Justiça do Estado de Rio Grande do Sul

TJDFT - Tribunal de Justiça do Distrito Federal e dos Territórios

REsp. - Recurso Especial

Apel. Cível - Apelação Cível

ADI - Ação Direta de Inconstitucionalidade

ADPF - Arguição de Descumprimento de Preceito Fundamental

PL - Projeto de Lei

CNJ - Conselho Nacional de Justiça

Rel. - Relator

Min. - Ministro

Des. - Desembargador

Ilmo. - Ilustríssimo

Art. - Artigo

CF/88 - Constituição Federal de 1988

CC/02 - Código Civil de 2002

$\S$ - Parágrafo 


\section{INTRODUÇÃO}

A homossexualidade é um fato social que está presente desde os primórdios da história da humanidade. Desde na antiga Grécia, assim como no Império Romano e na cidade de Esparta, o assunto era tratado com total normalidade, sendo a prática homossexual tão comum quanto a heterossexual. Por vezes era vista como um ritual de iniciação dos mais jovens como era o caso na Grécia Antiga ${ }^{1}$, ou até mesmo como forma de incentivar o companheirismo entre soldados para criar um exército forte e unido, como se fazia em sua famosa cidade-Estado Esparta ${ }^{2}$.

Assim, com o tempo, em grande parte por influencias advindas do surgimento das religiões diversas e o conceito de "pecado da carne", homossexualismo passou a sofrer o preconceito que, apesar de em menor escala, perdura até os dias atuais. Hoje, buscamos com muita dificuldade inserir o homossexual na sociedade como uma pessoa normal, sem vícios ou maiores defeitos do que qualquer outro ser humano heterossexual possa vir a ter.

Muitas vezes em discursos a favor do fim do preconceito é comum ouvirmos expressões como: opção sexual e tolerância. Daí surge a questão, será que mesmo estas expressões já não nos inclinam para estabelecer uma distinção entre o gay e o heterossexual?

\footnotetext{
${ }^{1}$ DIAS, Maria Berenice. União Homoafetiva - O preconceito e a Justiça - $5^{\mathrm{a}}$ ed. Rio de Janeiro: Revista dos Tribunais, 2012. p. 35 "Havia a crença de que, no período da infância e da puberdade, o jovem se identificava coma figura materna, fase abandonada pela iniciação homossexual, por meio da qual o menino adquiria identidade e se integrava à comunidade masculina. Antes de ser reconhecido como adulto, para se relacionar com o sexo oposto, o jovem devia incursionar em seu próprio gênero. A relação tinha caráter iniciatório e se restringia à ligação entre o homem mais velho e o menino ainda impúbere."

${ }^{2}$ DIAS, Maria Berenice. União Homoafetiva - O preconceito e a Justiça $-5^{\mathrm{a}}$ ed. Rio de Janeiro: Revista dos Tribunais, 2012. p. 34 "Na cidade de Esparta, cuja sociedade dava mais ênfase ao desenvolvimento militar do que ao cultural, o amor entre homens tinha enfoque um pouco diferenciado. Era estimulado dentro do exército, para torná-lo ainda mais eficiente. Isso se explica por um simples fato: quando o soldado ia para a guerra, não estaria lutando apenas por sua cidadeEstado; lutava também para proteger a vida do seu amado, aumentando, obviamente, o grau de dedicação e empenho do combatente."

${ }^{3}$ DIAS, Maria Berenice. União Homoafetiva - O preconceito e a Justiça - $5^{\mathrm{a}}$ ed. Rio de Janeiro: Revista dos Tribunais, 2012. p. 36
} 
Pois bem, quando se fala em "opção sexual", dá-se a impressão de que ser homossexual é uma escolha, como a própria palavra já indica, a pessoa supostamente optou por sua preferência sexual. Tal assertiva mostrase prejudicial aos homossexuais na medida em que a sociedade se vê no direito de ir contra tal suposta "opção", ou seja, é visto como apenas uma forma de agir e pensar que a pessoa escolheu e que terceiros não são obrigados a coadunar. Sem o reconhecimento de que a homossexualidade é inerente à pessoa, a luta contra o preconceito fica muito mais difícil por, na mente dos opositores, se tratar apenas de diferença de opiniões.

Já a tão utilizada expressão na luta a favor dos direitos homossexuais "tolerância", se pensada um pouco mais a fundo, pode ser fatal para disseminar o preconceito. Coloquialmente, a tolerância em referencia às relações pessoais é tida como algo negativo: ex: não gosto, mas tolero. Apesar de que, por definição, a tolerância é a virtude de "admitir, nos outros, maneiras de pensar, de agir e de sentir diferentes ou mesmo diametralmente opostas às nossas” ${ }^{\text {}}$. Portanto, acredito ser mais pertinente a utilização de expressões que não sejam capazes de gerar discussão como "igualdade", ou para quando houver necessidade de conjugação verbal, "praticar a igualdade".

O presente trabalho monográfico tem como objetivo a exposição de algumas das muitas lutas que os homossexuais têm travado para conseguir igualdade de direitos, sendo elas: o reconhecimento da união entre homossexuais como entidade familiar, o reconhecimento de todos os efeitos da união homoafetiva equiparados por completo aos da união estável e o casamento civil entre pessoas do mesmo sexo.

Tal tema é objeto de divergência em muitas partes do Globo estando alguns países anos-luz à nossa frente no que se refere ao respeito e inclusão dos casais homossexuais no ordenamento jurídico como iguais aos

\footnotetext{
${ }^{4}$ Definição de tolerância - Dicionário Houaiss: http://200.241.192.6/cgibin/houaissnetb.dll/frame?palavra=toler\%E2ncia
} 
heterossexuais. Podendo citar por alto: Dinamarca, desde 1989 reconhece a união-civil entre pessoas do mesmo sexo; Holanda, em 1998 aprovou a união civil e em 2001 o casamento; Noruega, em 1993, apesar de não prever a totalidade da igualdade com as uniões estáveis permitiu o registro civil das uniões homoafetivas; Israel, estado que adota a religião judaica com dogmas expressos proibindo as relações homossexuais, em 1994 editou legislação admitindo as parcerias homossexuais ${ }^{5}$. Além destes há muitos outros como Islândia, Alemanha e Nova Zelândia, o que nos leva a crer que as inovações referentes à união e o casamento entre pessoas do mesmo sexo que estão em voga no Brasil são apenas reflexos tardios de uma realidade social que outrora preferiam somente fechar os olhos, até que não houve mais escapatória.

Assim como será aprofundado mais a frente, a ADI n 4277 julgada em 05 de maio de 2011 e a Resolução CNJ n 175 de 14 de maio de 2013 já foram expressivos avanços em relação a tais questões, mesmo diante de muitas dúvidas e discussões que estas geraram pelos operadores do Direito. Sendo elas o início de um caminho a ser trilhado a favor da igualdade e do desenvolvimento legal, cultural e ideológico e da quebra de conceitos atrasados e odiosos que incitam a segregação de minorias em nosso país.

\footnotetext{
${ }^{5}$ DIAS, Maria Berenice. União Homoafetiva - O preconceito e a Justiça $-5^{\mathrm{a}}$ ed. Rio de Janeiro: Revista dos Tribunais, 2012. p. 58
} 


\section{Capítulo 1 - Evolução Histórica do conceito de família}

\section{1 - A Família Na Roma Antiga}

Ao iniciar o estudo sobre qualquer questão relacionada à família, mister faz-se observar a mutação sofrida pelo seu conceito ao longo da história. Deste modo, não poderia deixar de explorar o conceito de família presente no Direito Romano.

$\mathrm{Na}$ antiga Roma, berço de diversos institutos legais utilizados até hoje em nosso ordenamento jurídico, a família era vista de forma bem diversa do modelo atual. A família romana era uma grande família, constituída por parentes descendentes do mesmo tronco ancestral. Quando a mulher casava, saía de sua família de origem, perdendo inclusive direitos sucessórios, e, então, passava a ser parte apenas da família do marido.

O pater familias, ancestral mais velho vivo homem, congregava filhos, netos, cônjuges dos filhos, empregados, serviçais sobre o seu poder, sua autoridade. Esse poder (pátria potestas) era tão forte que ele o responsável pela distribuição da justiça, era o chefe político e até mesmo chefe religioso. O pater tinha até poder de vida e de morte sobre o filho podia sentenciá-lo à morte, lhe impor pena corporal e inclusive entregá-lo para a vítima na condição de escravo se ele cometesse um ato ilícito. Sobre o tema, relata o douto doutrinador Caio Mário da Silva Pereira:

"O pater era, ao mesmo tempo, chefe político, sacerdote e juiz. Comandava, oficiava o culto dos deuses domésticos (penates) e distribuía justiça. Exercia sobre os filhos direito de vida e de morte (ius vitae acnecis), podia imporlhes pena corporal, vendê-los, tirar-lhes a vida. A mulher vivia in loco filiae, totalmente subordinada à autoridade marital (in manu mariti), nunca adquirindo autonomia, pois que passava da condição de filha à esposa, sem alteração na sua capacidade; não tinha direitos próprios, era atingida por capitis deminutio perpétua que se justificava propter sexus infirmitatem et ignorantiam rerum forensium. Podia ser repudiada por ato unilateral do marido" 6

6 PEREIRA, Caio Mário da Silva. Instituições de Direito Civil - Volume V Direito de Família. $18^{\mathrm{a}}$ ed. Rio de Janeiro: Forense, 2010. p. 29 
A origem do poder familiar era a patria potestas, mas, se na época romana, o objetivo era fortalecer a autoridade do pater, o objetivo hoje é proteger a pessoa. Aos poucos, a patria potestas foi diminuindo. A primeira prerrogativa que o pai perdeu foi a de sentenciar o filho à morte.

Manus era o poder que o pater famílias exercia sobre a mulher e sobre as noras. No primeiro momento, o pater famílias era o único sui iuris, o único que tinha capacidade plena.

Assim, o pater famílias tinha poder sobre os filhos, sobre as mulheres e sobre o patrimônio - ele era o titular do patrimônio da família. Ele até podia conceder aos filhos uma espécie de procuração para que estes negociassem, mas apenas o faziam em nome do pater famílias.

Essa unidade patrimonial da família começa a ser quebrada quando se passa a admitir que os patrimônios que os filhos conquistassem com as guerras como soldados do Império tornassem-se seus, e não do pater famílias.

Claramente observa-se que a família na Roma antiga seguia um regime totalitário donde o centro de tudo era o patriarca. Um sistema hoje impensável em nossa sociedade contemporânea, mas que perdurou por muito tempo (segundo Caio Mario da Silva Pereira, pelo menos até o século IV, a era do imperador Constantino, visto que logo depois se instala no direito romano a concepção de família cristã ${ }^{7}$ ) e atua como alicerce do Direito Civil moderno.

\section{2- A Família no Direito Canônico}

A Igreja Católica tem uma importância massiva no processo de mutação do conceito de família ao longo da história. Isto porque, com os princípios do amor cristão aplicados em todos os aspectos da vida, ela 
acabou introduzindo o elemento afetivo na família, uma vez que esta antes não era vista como um centro de afeto, de compreensão.

Além disso, o Direito Canônico criou a figura do sacramento do casamento, ou seja, a união de um homem e uma mulher diante da Igreja era sagrada a ponto de criar um elo indissolúvel em vida. Ainda mais a fundo, a Igreja além de estar presente por completo na efetivação do matrimônio, passou a ditar regras de conduta para constância do mesmo, baseada na vontade divida. Sendo assim, o aborto passou a ser estritamente proibido, o adultério inconcebível e o concubinato uma aberração. Sobre tal assertiva, o douto doutrinador Caio Mario da Silva Pereira faz suas considerações:

"A Igreja somente empenhou-se realmente em combater tudo o que pudesse desagregar o seio familiar: $\mathrm{O}$ aborto, o adultério, e principalmente o concubinato, nos meados da Idade Média, com as figuras de Santo Agostinho e Santo Ambrósio; até então o concubinatus havia sido aceito como ato civil capaz de gerar efeitos tal qual o matrimônio. Os próprios reis mantiveram por muito tempo esposas e concubinas e até mesmo o clero deixou-se levar pelos desejos lascivos, contaminando-se em relações carnais e devassas, sendo muito comum a presença de mulheres libertinas dentro dos conventos." 8

Neste contexto, a mulher ainda possuía uma figura passiva no seio familiar, ela era a responsável pela criação dos filhos e pelos afazeres domésticos. O marido era o chefe da família e a esposa sua subordinada, tendo até que pedir permissão ao marido para se ausentar de casa.

Assim, ao longo da Idade Média, a família sofreu uma grande influência cristã. Além disso, a família passou a ir diminuindo por força das circunstancias históricas, e hoje evoluímos para a família nuclear, aquela composta basicamente pelos genitores e seus filhos, e que tem características completamente diferentes da família antiga. Essa era grande, o poder se concentrava nas mãos do ancestral mais velho vivo e ela era 
economicamente suficiente. Hoje a principal função da família é de afeto e de criação dos filhos.

\section{3 - A Família nas Constituições brasileiras pré 1988}

A Constituição de 1824 só tratava da família imperial, da sucessão e do seu aspecto de dotação. O capítulo III da "Constituicão Politica do Imperio do Brazil" intitulado: "Da Familia Imperial, e sua Dotação", apenas dispunha sobre como deveria se dar a contribuição para o sustento da família imperial e os direitos dos príncipes e princesas no que diz respeito a questões como a escolha dos mestres dos príncipes e o dote no casamento das princesas.

Já em 1891, foi promulgada a primeira Constituição republicana do Brasil, em seu texto constitucional, em seu artigo 72 , $\S 4^{\circ}$, estava disposto que o casamento reconhecido pelo Estado é o civil e sua celebração será gratuita. Ou seja, o casamento estava previsto na Constituição como a única forma de constituição de família, donde se entende tal instituição como um vínculo absoluto.

Tal fato se mostra deveras relevante, pois, quando não havia separação entre igreja e Estado, o casamento oficial era o religioso. Com a proclamação da República, houve a necessidade de se disciplinar o casamento civil e as regras para o mesmo, o que aconteceu em 24 de janeiro de 1890 pelo decreto 181. Assim, a Constituição de 1891 inovou em trazer este dispositivo que afirmava que o casamento civil era o oficial, disciplinado pelo Estado.

As Constituições posteriores, até 1967/1969, assim dispuseram também - tratavam da família constituída pelo casamento, era a família legítima (as fora do casamento eram ilegítimas), que merecia especial proteção do Estado, e o vínculo era indissolúvel. 
A Emenda Constitucional $\mathrm{n}^{\mathrm{o}} 9$ de 28 de junho de 1977, alterou o texto do parágrafo $1^{\circ}$ do artigo 175 da Constituição Federal de 1969 que deixou de prever a indissolubilidade do casamento e passou a dispor que o casamento poderia ser dissolvido nos casos expressos em lei, exigindo para tal a separação de fato por três anos. Com isso, tornou-se evidentemente necessária a edição de uma legislação para regular o divórcio.

A lei 6515/77 disciplinou o divórcio - deixou-se de ter o desquite e surgiu a figura da separação judicial. Na prática, não houve tanta modificação de um para o outro, simplesmente foi positivado e renomeado o que antes era conhecido como Desquite por Separação, tanto em sua forma consensual quanto litigiosa. Interessante frisar que o artigo 38 da referida Lei, talvez pelo fato do legislador da época ainda adotar a ideia do paternalismo estatal sobre a família, dispunha que só se poderia pedir o divórcio uma vez, tendo a norma sido revogada com o advento da Constituição Federal de 1988, mais especificamente pela Lei nº .7 .841 , de 17 de outubro de 1989.

Assim, observa-se que até a Constituição de 1988, só tínhamos como merecedora de proteção, mencionada na Constituição, a família matrimonial, com o detalhe que desde 1977 em diante não mais era considerada indissolúvel. Visto isso, fácil concluir que existiam diversas lacunas na lei no que se referia às formas de família, quiçá por uma evolução cultural demasiadamente lenta e gradual no que diz respeito a tais conceitos. A partir de 1988 até os dias atuais, foi-se tornando claro que não era mais possível continuar fechando os olhos para os outros tipos de família que existem em nossa sociedade. Sobre o tema, segue brilhante reflexão da ilustre doutrinadora Maria Berenice Dias:

"O legislador não consegue acompanhar a realidade social nem contemplar as inquietações da família contemporânea. A sociedade evolui, transforma-se, rompe com tradições e amarras, o que gera a necessidade de constante oxigenação das leis. A tendência é simplesmente proceder à atualização normativa, sem absorver o espírito das silenciosas mudanças alcançadas no seio 
social, o que fortalece a manutenção da conduta de apego à tradição legalista, moralista e opressora da lei. O influxo da chamada globalização impõe constante alteração de regras, leis e comportamentos. No entanto, a mais árdua tarefa é mudar as regras do direito das famílias. Quando se trata das relações afetivas afinal, é disso que trata o direito das famílias -, a missão é muito mais delicada em face de seus reflexos comportamentais que interferem na própria estrutura da sociedade. É o direito que diz com a vida das pessoas, seus sentimentos, enfim, com a alma do ser humano. Como adverte Sérgio Gischkow Pereira, o regramento jurídico da família não pode insistir, em perniciosa teimosia, no obsessivo ignorar das profundas modificações culturais e científicas, petrificado, mumificado, cristalizado em um mundo irreal, ou sofrerá o mal da ineficácia." ${ }^{9}$

"A lei nunca se preocupou em definir a família - limitava-se a identificála com o casamento. Esta omissão excluía do âmbito jurídico todo e qualquer vínculo de origem afetiva que leva à comunhão de vidas e embaralhamento de patrimônios. O resultado sempre foi desastroso, pois levou a Justiça a condenar à invisibilidade e negar direitos a quem vivia aos pares, mas sem a chancela estatal." 10

\section{4 - Inovações trazidas pela Constituição de 1988}

Do Código Cívil de 1916 à Constituição de 1988, o Direito de Família evoluiu consideravelmente. O Código Civil de 2002 ainda é impregnado pela visão do código de 1916 de família formada pelo casamento, ao passo que a Constituição de 1988 trata de família de forma mais plural. Do artigo 1511 ao 1927, o CC/02 trata de Direito de Família, mas apenas 4 (quatro) destes são dedicados à União estável. Destarte, pela pluralidade familiar, a $\mathrm{CF} / 88$ é ainda mais avançada e, por isso, mais apropriada para tratar do assunto. Assim, a nossa constituição é uma constituição das famílias e, por isto, o mais correto hoje é falar em Direito das Famílias, ao em vez de Direito de Família.

Todas as Constituições anteriores tratavam família como sendo aquela formada pelo casamento. Era, portanto, necessário um ato jurídico, ou seja, a celebração de casamento. Todavia, a tendência da advocacia levou a construir a teoria da sociedade de fato, deslocando a família para o Direito Societário. Sociedade é um contrato com finalidade econômica

9 Dias, Maria Berenice. Manual de Direito das Famílias. $6^{\text {a }}$ ed. São Paulo: Revista dos Tribunais, 2010. p. 29

10 Ibid. p. 43 
celebrado entre pessoas. Por essa teoria, o casamento é colocado como uma comunhão de esforços para um dado fim econômico. Naquela época, o que ocorria fora do casamento não gerava tantos direitos como atualmente. Hoje, o vínculo familiar não surge apenas com a celebração do casamento.

A Constituição de 1988 rompe com o paradigma da família formada com o casamento sem definir o que é família. Por outro lado, ela nos apresenta modelos de família: casamento; união estável entre o homem e a mulher; comunidade formada por qualquer dos pais e por seus descendentes, chamada família monoparental (artigo 226, parágrafos 1 ao 4 da $\mathrm{CF} / 88$ ). Por existirem diversos modelos, é que, repito, o correto atualmente seria dizer Direito das Famílias. Isso é uma evolução no sentido de que a formação do vínculo familiar está mais ligada ao vínculo fático afetivo ao invés de apenas um ato formal.

Sobre o exposto, o doutrinador Marco Túlio de Carvalho Rocha dispõe que:

"No Brasil, embora os novos princípios tenham ganhado espaço, paulatinamente, durante todo o século XX, a Constituição da República de 1988 é o marco dessas transformações, por ter consagrado a igualdade dos cônjuges e a dos filhos, a primazia dos interesses da criança e do adolescente, além de ter reconhecido, expressamente, formas de famílias não fundadas no casamento, às quais estendeu a proteção do Estado" 11

Daqui decorre uma questão: o rol de modelos de família apresentado pela Constituição é um rol taxativo ou exemplificativo? A maioria da doutrina entende que este rol é exemplificativo. Entende essa parte da doutrina que o legislador não teve intenção de limitar ou impedir que outras formas de família se constituíssem. Desta forma, entende o ilustre doutrinador Cristiano Chaves de Farias:

"Fica claro, portanto, que a interpretação de todo o texto constitucional deve ser fincada nos princípios da liberdade e igualdade, despida de qualquer preconceito, porque tem como "pano de fundo" o princípio da dignidade da

11 ROCHA, Marco Túlio de Carvalho. O conceito de família e suas implicações jurídicas: teoria sociojurídica do direito de família. Rio de Janeiro: Elsevier, 2009, p. 01. 
pessoa humana, assegurado logo pelo art. $1^{\circ}$, III, como princípio fundamental da República (motor de impulsão de toda a ordem jurídica brasileira).

Sem dúvida, então, a única conclusão que atende aos reclamos constitucionais é no sentido de que o rol não é, e não pode ser nunca taxativo, por deixar sem protecão inúmeros agrupamentos familiares, não previstos no texto constitucional, até mesmo por absoluta impossibilidade.

Não fosse só isso, ao se observar a realidade social premente, verificando-se a enorme variedade de arranjos familiares existentes, apresentar-se-ia outro questionamento: seria justo que os modelos familiares, não previstos em lei, não tenham proteção legal?" (grifou-se) ${ }^{12}$

Na mesma linha, Paulo Lôbo ensina que:

"Os tipos de entidades familiares explicitados nos parágrafos do art. 226 da Constituição são meramente exemplificativos, sem embargo de serem os mais comuns, por isso mesmo merecendo referência expressa. As demais entidades familiares são tipos implícitos incluídos no âmbito de abrangência do conceito amplo e indeterminado de família, indicado no caput. Como todo conceito indeterminado, depende de concretização dos tipos, na experiência da vida, conduzindo à tipicidade aberta, dotada de ductilidade $\mathrm{e}$ adaptabilidade". (grifou-se) $)^{13}$

A partir daí surge a noção de que, diante da assertiva de que não há um rol limitador acerca dos tipos de família, quem dita o que é família ou não é a própria sociedade. As relações entre pessoas baseadas no afeto acabam que por si só se impõem de maneira positiva como famílias, assim como a união homoafetiva que mais a frente será abordada, fazendo com que esta abertura interpretativa da Constituição Federal de 1988 figure como uma evolução necessária para andar ao lado do desenvolvimento da cultura e costumes sociais.

12 [6] FARIAS, Cristiano Chaves de. Direito constitucional à família (ou famílias sociológicas 'versus' famílias reconhecidas pelo direito: um bosquejo para uma aproximação conceitual à luz da legalidade constitucional). Revista da Escola Superior da Magistratura de Sergipe, $n^{\circ}$ 03, 2002, p. $5-6$.

13 LÔBO, Paulo, Direito Civil - Famílias, São Paulo: ed. Saraiva, 2a ed., 2009, p. 61 


\section{CAPÍTULO 2 - O CARÁTER AFETIVO}

\section{1 - Conceito de afeto}

O afeto vem tomando cada vez mais seu espaço no Direito de Família, sua aplicação passou de meramente terminológica para principiológica, hoje se fala em princípio da afetividade, sendo este extrínseco, porém implícito à Constituição Federal tendo em vista sua adequação ao princípio da dignidade humana disposto em seu art. $1^{\circ}$, III ${ }^{14}$. Nas palavras do Ilustríssimo doutrinador Caio Mario da Silva Pereira:

"O princípio jurídico da afetividade, em que pese não estar positivado no texto constitucional, pode ser considerado um princípio jurídico, à medida que seu conceito é construído por meio de uma interpretação sistemática da Constituição Federal (art. $5^{\circ}, \S 2^{\circ}, \mathrm{CF}$ ) princípio é uma das grandes conquistas advindas da família contemporânea, receptáculo de reciprocidade de sentimentos e responsabilidades. Pode-se destacar um anseio social à formação de relações familiares afetuosas, em detrimento da preponderância dos laços meramente sanguíneos e patrimoniais." 15

Já no Código Civil pode-se observar o afeto explícito no que diz respeito à guarda dos filhos em seu art. $1.583,2 \S, \mathrm{I}^{16}$, e apenas implícito no que diz respeito às formações das famílias, dando asas a interpretações diversas e por vezes equivocadas. Sobre o tema leciona Maria Berenice Dias:

"O Código Civil utiliza a palavra afeto somente para identificar o genitor a quem deve ser deferida a guarda unilateral (CC $1.583 \S 2 .^{\circ}$ I). Invoca somente a relação de afetividade como elemento indicativo para definição da guarda a favor de terceira pessoa (CC $1.583 \S 5^{\circ}{ }^{\circ}$ ). Ainda que com grande esforço se consiga visualizar na lei a elevação do afeto a valor jurídico ${ }^{17}$, mister reconhecer que tímido mostrou-se o legislador." 18

14 Constituição Federal: Art. $1^{\circ}$. A República Federativa do Brasil, formada pela união indissolúvel dos Estados e Municípios e do Distrito Federal, constitui-se em Estado Democrático de Direito e tem como fundamentos; III - a dignidade da pessoa humana.

15 PEREIRA, Caio Mário da Silva. Instituições de Direito Civil - Volume V Direito de Família. $18^{\mathrm{a}}$ ed. Rio de Janeiro: Forense, 2010. p. $55-56$.

16 Lei $n^{0} 10.406$, de 10 de janeiro de 2002: Art. 1.583. A guarda será unilateral ou compartilhada; $\S 2^{\circ}$ A guarda unilateral será atribuída ao genitor que revele melhores condições para exercê-la e, objetivamente, mais aptidão para propiciar aos filhos os seguintes fatores: I - afeto nas relações com o genitor e com o grupo familiar.

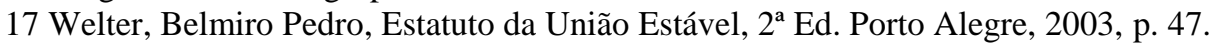

18 Dias, Maria Berenice. Manual de Direito das Famílias. $6^{\text {a }}$ ed. São Paulo: Revista dos Tribunais, 2010 , p. 71 
$\mathrm{Na}$ busca do conceito literal de afeto, mostra-se pertinente a definição elaborada pelo filósofo italiano Abbagnano que diz que afeição é usado filosoficamente "em sua maior extensão e generalidade, porquanto designa todo estado, condição ou qualidade que consiste em sofrer uma ação sendo influenciado ou modificado por ela" ${ }^{\text {"19 }}$. Como corolário, o rol de emoções contempladas pelo afeto abarca não somente aquelas positivas como a amizade e o amor, mas também as negativas, tais como a ira e os ciúmes.

$\mathrm{O}$ afeto, como termo, alcança tanto emoções positivas quanto emoções negativas; contudo, o afeto, como princípio, alcança, quanto às emoções negativas, somente aquelas provenientes de emoções positivas. Isso é possível ser dito porque o afeto, como princípio, deve se acomodar à forma representada pela família, uma vez ter daí se originado e sido pinçado pelos dispositivos legais, jurisprudência e doutrina. Se o intuito de se introduzir tal princípio no mundo jurídico foi o de humanizar a família, não pode o mesmo ser satisfeito pela observação no caso concreto de qualquer tipo de emoção. Deve-se atentar que uma determinada emoção negativa pode ser decorrente de uma obrigação moral ou jurídica, por exemplo, o que descaracterizaria o afeto familiar.

O princípio da afetividade no Direito das Famílias consiste, em síntese apertada, na disposição de sentimentos que dão a uma relação caráter familiar, sejam estes positivos ou negativos, porém sempre tendo início por sentimentos positivos.

Certos aspectos afetivos no seio familiar são inconfundíveis, impossibilitando restrições baseadas apenas na forma, tornando qualquer tentativa de estabelecer um rol legal taxativo de famílias ineficaz e ultrapassado. Sendo assim, em uma relação duradoura envolvendo sentimentos de amor, respeito e reciprocidade, resta evidente a 
caracterização do vínculo familiar. Sobre o tema, segue valiosa lição de Maria Berenice Dias:

"A família transforma-se na medida em que se acentuam as relações de sentimentos entres seus membros: valorizam-se as funções afetivas da família. ${ }^{20}$ Despontam novos modelos de família mais igualitárias nas relações de sexo e idade, mais flexíveis em suas temporalidades e em seus componentes, menos sujeitas à regra e mais ao desejo, na expressão de Michel Perrot. ${ }^{21} \mathrm{~A}$ família e o casamento adquiriram novo perfil, voltados muito mais a realizar os interesses afetivos e existenciais de seus integrantes. Essa é a concepção eudemonista da família, que progride à medida que regride o seu aspecto instrumental. ${ }^{22} \mathrm{~A}$ comunhão de afeto é incompatível com o modelo único, matrimonializado, da família. Por isso, a afetividade entrou nas cogitações dos juristas, buscando explicar as relações familiares contemporâneas. ${ }^{23} .,{ }^{24}$

\section{2 - O princípio da afetividade nas relações homoafetivas}

A afetividade hoje já é reconhecida como o maior princípio que norteia as relações familiares modernas. Mais importante que isso, na concepção moderna de família é o afeto que, acima da letra fria da Lei, delimita o que é família, ou seja, quais relações podem ser tidas como familiares.

Neste sentido, Rodrigo da Cunha Pereira entende que:

"Sem afeto não se pode dizer que há família. Ou, onde falta o afeto a família é uma desordem, ou mesmo uma desestrutura. É o 'afeto que conjuga'. E assim, o afeto ganhou status de valor jurídico e, consequentemente, logo foi elevado à categoria de princípio como resultado de uma construção histórica em que o discurso psicanalítico é um dos principais responsáveis, vez que o desejo e amor começam a ser vistos e considerados como verdadeiro sustento do laço conjugal e da família." ${ }^{25}$

Em tal concepção percebe-se um avanço significativo, tendo que vista que por vezes ao longo da história famílias consideradas não

20 OLIVEIRA, José Lamartine Corrêa de; MUNIZ, Francisco José Ferreira. Direito de Família. Porto Alegre: Fabris, 1990, p. 11.

21 PERROT, Michelle. O Nó e o Ninho. Veja: Reflexões para o futuro - 1993, p. 01.

22 OLIVEIRA, José Lamartine Corrêa de; MUNIZ, Francisco José Ferreira. Direito de Família. Porto Alegre: Fabris, 1990, p. 11.

23 LÔBO, Paulo Luiz Netto. Código Civil Comentado: Famílias, $3^{a}$ Ed. São Paulo: Saraiva, 2010, p. 41.

24 Dias, Maria Berenice. Manual de Direito das Famílias. $6^{\text {a }}$ ed. São Paulo: Revista dos Tribunais, 2010 , p.71- 72 .

25 PEREIRA, Rodrigo da Cunha. Princípio da afetividade. In DIAS, Maria Berenice (coord.).

Diversidade sexual e direito homoafetivo. São Paulo: Revista dos Tribunais, 2011, p. 194. 
convencionais pelos legisladores foram deixadas de lado como se não existissem. $\mathrm{O}$ afeto como modo de identificação de famílias não deixa mais dúvidas acerca da validade do reconhecimento do vínculo familiar da união homoafetiva. Pela própria análise etimológica da palavra já se observa o afeto como requisito para sua própria existência - homo-afetiva - afeto homossexual.

Sobre o tema, Maria Berenice Dias em sua recente obra: "União Homoafetiva - O preconceito e a Justiça" destaca a enorme relevância do caráter afetivo no que diz respeito ao direito das famílias como um todo, tendo o princípio afetivo se tornado o mais importante para seu estudo e aplicação. Da magnífica obra cabe ressaltar o seguinte trecho:

"Cada vez mais se valoriza as funções afetivas da família. Basta atentar a toda uma nova terminologia: filiação socioafetiva, dano afetivo etc. E, na medida em que se acentuam as relações de sentimentos entre os seus membros a família se transforma. Foi o afeto e o princípio da afetividade que trazem legitimidade a todas as formas de família. Portanto, hoje, todas as relações e formações da família são legítimas.

Com a consagração do afeto a direito fundamental, não há como deixar de reconhecer que as uniões afetivas entre pessoas do mesmo sexo também são marcadas pelo elo da afetividade. Outra não foi a razão para identificar tais vínculos familiares: uniões homoafetivas.

Talvez nada mais seja necessário dizer para evidenciar que o princípio norteador do direito das famílias é o princípio da afetividade." ${ }^{26}$

Não há o que se discutir em relação à existência de afeto em relações homossexuais. A comunhão de vida baseada em respeito, amor, reciprocidade e demais sentimentos conjugais e familiares são igualmente partilhados tanto por casais homossexuais quanto heterossexuais. Seria puro preconceito e ignorância não reconhecer tal vínculo afetivo, e, sendo reconhecido, é mais um tipo de família merecedora de proteção e inclusão no Direito pátrio.

Visto isto, cabe citar que a união estável, instituto hoje conhecido por todos e amplamente aceitado sem nenhuma discussão acerca de sua 
validade, outrora foi omitido do projeto de Lei do Código Civil de 2002. Segundo afirmação de Silvio Rodrigues em sua obra de 2002 que estudava o Direito de Família no, recente à época, Novo Código Civil, em torno de 1982 não se cogitava a proteção legal da união estável, a saber:

"O Título III é dedicado à união estável e seus efeitos. Estranha a sistematização, mas justificada a inclusão em separado dessa entidade familiar, pois na versão primitiva do projeto, elaborado há mais de duas décadas, não se cogitava da proteção dessa forma de estabelecimento de família."27

Portanto, nos tempos modernos de hoje é absurdo pensar que pessoas do sexo oposto unidas que estabelecem convivência duradoura com objetivo de constituir família não sejam reconhecidas como entidade familiar, porém, um dia assim foi pensado. Graças ao desenvolvimento cultural e desprendimento de dogmas que abominam qualquer relação de casal que não seja casamento entre homem e mulher, a união estável, com base no princípio da afetividade, foi considerada como entidade familiar. Assim, claro resta que o mesmo se aplica para as uniões homoafetivas, com o detalhe de que nosso ordenamento jurídico, apesar de caminhando pelo rumo correto, já está muito atrasado em relação a esta.

\footnotetext{
${ }^{27}$ RODRIGUES, Silvio - Direito Civil - Direito de Família - Volume 6 - 27 ed. São Paulo: Saraiva, 2002, p. 15.
} 


\section{CAPÍTULO 3 - A UNIÃO HOMOAFETIVA}

\section{1 - O projeto de Lei $2.285 / 2007$}

Em 25 de outubro de 2007, o IBDFAM - Instituto Brasileiro de Direito da Família apresentou o projeto de Lei $\mathrm{n}^{\circ}$ 2.285/2007 que consistia na criação do Estatuto das Famílias, sendo este reconhecido por Maria Berenice Dias como "arrojada proposta legislativa que exclui o Livro de Direito de Família do Código Civil e positiva o Direito das Famílias de modo mais adequado a sociedade contemporânea" 28.

Tal assertiva da douta doutrinadora Maria Berenice Dias encontra-se por demais correta tendo em vista que o Estatuto das Famílias busca uma visão mais moderna e constitucionalizada do Direito de Família, ou, como já defendido no presente trabalho e utilizado pela Autora, Direito das Famílias, sendo suas disposições regidas e interpretadas pelos princípios da "dignidade da pessoa humana, a solidariedade familiar, a igualdade de gêneros, de filhos e das entidades familiares, a convivência familiar, o melhor interesse da criança e do adolescente e a afetividade" ${ }^{29}$.

Do disposto acima, importante enfatizar em especial a inclusão do princípio da afetividade no rol de diretrizes norteadoras do referido projeto. Destarte, como já fatalmente as entidades familiares perante a sociedade já são reconhecidas em consonância com o princípio da afetividade, sua positivação no Direito Pátrio seria um avanço de suma importância para quebrar as barreiras dogmáticas que atrasam o desenvolvimento cultural e disseminam o preconceito no país.

Cabe citar trecho do livro do renomado doutrinador Washington de Barros Monteiro onde o Autor, já em 1995, reconhece que quando o legislador intervém no direito de família é porque a sociedade e todos os

28 DIAS, Maria Berenice. União Homoafetiva - O preconceito e a Justiça - $5^{\text {a }}$ ed. Rio de Janeiro: Revista dos Tribunais, 2012. p. 79

29 PL 2.285/2007 - Estatuto das Famílias - Título I, art. 5. 
profissionais das áreas humanas, inclusive do Direito, já estão cientes e de acordo com a matéria, sendo a Lei em si somente uma positivação de um costume e a proteção pelo âmbito familiar legal do mesmo:

"Não olvidemos, porém, que o legislador só intervém quando forçado; se ele interfere no direito de família é porque naturalmente percebe, como os jurisconsultos, os moralistas e os sociólogos, a importância da família, acorrendo, pois, em seu auxílio, curvando-se aos novos costumes, a exigirem modificações legislativas.

Efetivamente, cada vez mais, torna-se pronunciada a intervenção do Estado nessa parte do direito civil. Nossa legislação não escapa a tal tendência, generalizada e universal." ${ }^{, 30}$

O projeto 2.285/2007 vai ainda mais além, isto pois dispõe em seu art. $3^{\circ}$ que: "É protegida como família toda comunhão de vida instituída com a finalidade de convivência familiar, em qualquer de suas modalidades." 31

Em relação ao dispositivo susoreferido, primeiramente cabe destacar a extinção da ideia ultrapassada de família ser sinônimo de união entre homem e mulher, a comunhão de vida não tem limitações por sexo, exigindo apenas o animus de convivência familiar. Após, observa-se que no final do texto legal é reconhecida a existência de modalidades diversas de família, o que somente reforça a interpretação extensiva do conceito, abrangendo assim tanto as famílias homoafetivas como as monoparentais, paralelas, anaparentais e etc.

$\mathrm{O}$ projeto, em seu Capítulo IV, art. 68, faz uma alusão direita às uniões homoafetivas e as reconhece como forma de família com direitos iguais à união estável, reconhecendo até o direito a adoção, herança, guarda de filhos, entre outros. Verbis:

"É reconhecida como entidade familiar a união entre duas pessoas de mesmo sexo, que mantenham convivência pública, contínua, duradoura, com

\footnotetext{
${ }^{30}$ MONTEIRO, Washington de Barros. Curso de Direito Civil - Direito de Família - $32^{\mathrm{a}}$ ed. São Paulo: Saraiva, 1995, p. 05.

31 PL 2.285/2007 - Estatuto das Famílias - Título I, art. $3^{\circ}$.
} 
objetivo de constituição de família, aplicando-se, no que couber, as regras concernentes à união estável.

Parágrafo único. Dentre os direitos assegurados, incluem-se:

I - guarda e convivência com os filhos;

II - a adoção de filhos;

III - direito previdenciário;

IV - direito à herança." 32

O Estatuto das Famílias mostra-se como uma iniciativa de avanço não só para o Direito brasileiro, mas como para sociedade como um todo, uma evolução de pensamentos e adequação a novas realidades. Aparentemente, à época da votação pela Câmara dos deputados, tais inovações não geraram contentamento no que diz respeito às uniões homoafetivas, tendo o projeto sido aprovado com a exclusão de todas as referências à união homoafetiva, pendendo ainda recurso para o Senado Federal. $^{33}$

\section{2 - Jurisprudência pré ADI 4277}

\subsection{1 - Jurisprudência Favorável ao Reconhecimento da União Homoafetiva}

O reconhecimento da união homoafetiva já é questão debatida no judiciário bem antes da tardia decisão do STF na ADI 4277 que a julgou de uma vez por todas. A jurisprudência era dividida basicamente em: não reconhecimento da união entre homossexuais como entidade familiar, apenas como sociedade de fato; reconhecimento da união homoafetiva como válida e, por consequência, como entidade familiar podendo assim gerar seus efeitos legais em questões como de herança, pensão, separação, etc.

32 PL 2.285/2007 - Estatuto das Famílias - Título III, Capítulo IV, art. 68.

33 DIAS, Maria Berenice. União Homoafetiva - O preconceito e a Justiça $-5^{\text {a }}$ ed. Rio de Janeiro: Revista dos Tribunais, 2012. p. 79. 
Em 19 de outubro de 2005, o Tribunal de Justiça do Rio de Janeiro, mesmo sem apreciar o mérito da questão, tendo apenas atribuição para definir a competência para julgamento da Ação de Reconhecimento de União Estável com Pedido de Alimentos entre homossexuais, tangenciou de forma expressiva a questão da validade da união estável entre homossexuais, reconhecendo seus direitos constitucionalmente protegidos que norteiam tal relação, a saber:

\begin{abstract}
“Ação de Reconhecimento de União Estável com Pedido de Alimentos - Sentença terminativa, proferida por Juízo de Família, com base em impossibilidade jurídica da demanda. A Constituição Federal, nos artigos $3^{\circ}$, inciso IV e $5^{\circ}$, incisos I e $\underline{X}$, veda qualquer tipo de preconceito ou forma de discriminacão, inclusive à concernente ao sexo, elevando à categoria dos direitos e garantias fundamentais a igualdade de todos perante a lei. $O$ artigo 226 e seus parágrafos $3^{\circ}$ e $4^{\circ}$ da Magna Carta, ao estabelecerem que a família é a base da sociedade e tem especial protecão do Estado, reconhecendo a união estável entre o homem e a mulher como entidade familiar, bem como a comunidade formada por qualquer dos pais e seus descendentes, não pretendeu excluir a existência e a possibilidade de reconhecimento de $\underline{u n i o ̃ e s ~ h o m o a f e t i v a s, ~ s o b ~ p e n a ~ d e ~ v i o l a c ̧ a ̃ o ~ d o s ~ p r e c e i t o s ~ c o n s t i t u c i o n a i s . ~} \underline{0}$ relacionamento entre dois homens ou entre duas mulheres é fato social aceito e reconhecido por toda a sociedade, não sendo possível negar-se a realidade que ocorre no País e no mundo, inclusive existe Projeto de Lei tramitando no Congresso Nacional para regulamentar o relacionamento homoafetivo. $\mathrm{Na}$ ausência de lei expressa sobre a matéria, aplica-se o artigo $4^{\circ}$ da Lei de Introdução ao Código Civil, cabendo ao juiz decidir o caso de acordo com a analogia, os costumes e os princípios gerais de direito. A competência para processar e julgar a questão é de uma das Varas Cíveis, por falta de previsão expressa das Leis Processuais e do Código de Organização e Divisão Judiciárias do Estado do Rio de Janeiro atribuindo a competência a uma das Varas de Família - Prevalece a competência residual das Varas Cíveis. Assim, reforma-se a Sentença, determinando-se o prosseguimento do feito perante uma das Varas Cíveis da Comarca de Niterói até ulterior sentença de mérito." ( grifou-se) ${ }^{34}$
\end{abstract}

O douto julgador elencou os preceitos constitucionais da igualdade $\mathrm{e}$ da proteção à família para fazer um contraponto com a expressão "entre homem e mulher" no que diz respeito à união estável na Constituição Federal de 1988. De forma clara e concisa, o ilustre jurista expôs seu entendimento de que não há limitação constitucional em reconhecer união estável entre dois homens e duas mulheres, tendo em vista sua incoerência com os princípios maiores da Carta Magna.

\footnotetext{
${ }^{34}$ TJRJ, $17^{\circ}$ Câmara Cível, proc. nº 0027413-41.2004.8.19.0002, Rel. Camilo Ribeiro Ruliere, julgado em 19/10/2005.
} 
No disposto pelo julgado acima analisado, pode-se retirar a seguinte conclusão: não há caráter dogmático quando se fala em união estável entre homem e mulher, não haveria esta possibilidade, pois reconhecidamente seria uma afronta à igualdade e dignidade das minorias excluídas desta definição. Sendo assim, entendimentos neste sentido sempre se mostraram um passo à frente para a lenta e necessária evolução ideológica que caminha até os dias atuais.

Sobre o princípio constitucional da igualdade, Celso Antonio Bandeira de Mello dispõe que:

“[...], por via do princípio da igualdade, o que a ordem jurídica pretende firmar é a impossibilidade de desequiparações fortuitas ou injustificadas. Para atingir este bem, este valor absorvido pelo Direito, o sistema normativo concebeu fórmula hábil que interdita, o quanto possível, tais resultados, posto que, exigindo igualdade, assegura que os preceitos genéricos, os abstratos e atos concretos colham a todos sem especificações arbitrárias, assim proveitosas que detrimentosas para os atingidos" ${ }^{35}$ (grifou-se)

Em relação ao princípio também protegido em nossa Carta Magna da dignidade da pessoa humana, cabe citar valiosa lição de Ingo Wolfgang Sarlet acerca do tema:

"Tem-se por dignidade da pessoa humana a qualidade intrínseca e distintiva reconhecida em cada ser humano que o faz merecedor do mesmo respeito e consideração por parte do Estado e da comunidade, implicando, neste sentido, um complexo de direitos e deveres fundamentais que assegurem a pessoa tanto contra todo e qualquer ato de cunho degradante e desumano, como venham a lhe garantir as condições existenciais mínimas para uma vida saudável, além de propiciar e promover sua participação ativa e corresponsável nos destinos da própria existência e da vida em comunhão com os demais seres humanos." 36

Em decisão proferida em 2007, o Tribunal do Rio Grande do Sul reconheceu que existe lacuna na Lei no que diz respeito ao reconhecimento da união homoafetiva, devendo assim ser equiparada à união estável e não a uma sociedade de fato, tendo em vista o seu aspecto afetivo. Assim, tendo

\footnotetext{
35 BANDEIRA de MELLO, Celso Antônio. Conteúdo Jurídico do princípio da igualdade. 3 ed. São Paulo: Malheiros, 1999. p. 18.

36 SARLET, Ingo Wolfgang. Dignidade da Pessoa Humana e Direitos Fundamentais na Constituição Federal de 1988. $3^{a}$ ed. Porto Alegre: Livraria do Advogado, 2004, p. 60.
} 
feita a analogia ao art. 1.723 e reconhecido a existência dos pressupostos para a união estável, o douto julgador tratou a separação do casal homossexual como entidade familiar e, portanto, merecedora de proteção pelo Livro referente ao Direito de Família do Código Civil.

“APELAÇÃO CÍVEL. UNIÃO HOMOSSEXUAL. RECONHECIMENTO DE UNIÃO ESTÁVEL. SEPARAÇÃO DE FATO DO CONVIVENTE CASADO.

PARTILHA DE BENS. ALIMENTOS. União homossexual: lacuna do Direito. O ordenamento jurídico brasileiro não disciplina expressamente a respeito da relação afetiva estável entre pessoas do mesmo sexo. Da mesma forma, a lei brasileira não proíbe a relação entre duas pessoas do mesmo sexo. Logo, está-se diante de lacuna do direito. Na colmatação da lacuna , cumpre recorrer à analogia, aos costumes e aos princípios gerais de direito, em cumprimento ao art. 126 do CPC e art. $4^{\circ}$ da Lei de Introdução ao Código Civil Na busca da melhor analogia, o instituto jurídico, não é a sociedade de fato. A melhor analogia, no caso, é a com a união estável. $O$ par homossexual não se une por razões econômicas. Tanto nos companheiros heterossexuais como no par homossexual se encontra, como dado fundamental da união, uma relacão que se funda no amor, sendo ambas relações de índole emotiva, sentimental e afetiva. Na aplicação dos princípios gerais do direito a uniões homossexuais se vê protegida, pelo primado da dignidade da pessoa humana e do direito de cada um exercer com plenitude aquilo que é próprio de sua condicãa. Somente dessa forma se cumprirá à risca, o comando constitucional da não discriminação por sexo. A análise dos costumes não pode discrepar do projeto de uma sociedade que se pretende democrática, pluralista e que repudia a intolerância e o preconceito. Pouco importa se a relação é hétero ou homossexual. Importa que a troca ou o compartilhamento de afeto, de sentimento, de carinho e de ternura entre duas pessoas humanas são valores sociais positivos e merecem protecão jurídica. Reconhecimento de que a união de pessoas do mesmo sexo, geram as mesmas consequiências previstas na união estável. Negar esse direito às pessoas por causa da condição e orientação homossexual é limitar em dignidade a pessoa que são. A união homossexual no caso concreto. Uma vez presentes os pressupostos constitutivos da união estável (art. 1.723 do CC) e demonstrada a separação de fato do convivente casado, de rigor o reconhecimento da união estável homossexual, em face dos princípios constitucionais vigentes, centrados na valorização do ser humano. Via de consequiência, as repercussões jurídicas, verificadas na união homossexual, tal como a partilha dos bens, em face do princípio da isonomia, são as mesmas que decorrem da união heterossexual. DERAM PARCIAL PROVIMENTO AO APELO." ${ }^{37}$ (grifou-se)

O próprio STJ já vinha reconhecendo a lacuna da lei e mantendo as decisões de segundo grau que reconheciam a União Homoafetiva como entidade familiar, análoga à União Estável. Em decisão de 2008 tal reconhecimento foi explicitado de forma a entender que a Lei não coíbe a União entre pessoas do mesmo sexo, somente é silente no que diz respeito à

37 TJRS, $8^{\text {a }}$ Câmara Cível, Apelação Cível n n 70021637145, Rel. Rui Portanova, julgado em 13/12/2007. 
mesma, devendo assim o julgador sanar tal lacuna com base nos princípios constitucionais vigentes, a saber:

"PROCESSO CIVIL. AÇÃO DECLARATÓRIA DE UNIÃO HOMOAFETIVA. PRINCÍPIO DA IDENTIDADE FÍSICA DO JUIZ. OFENSA NÃO CARACTERIZADA AO ARTIGO 132, DO CPC. POSSIBILIDADE JURÍDICA DO PEDIDO. ARTIGOS $1^{\circ}$ DA LEI 9.278/96 E 1.723 E 1.724 DO CÓDIGO CIVIL. ALEGAÇÃO DE LACUNA LEGISLATIVA. POSSIBILIDADE DE EMPREGO DA ANALOGIA COMO MÉTODO INTEGRATIVO.

1. Não há ofensa ao princípio da identidade física do juiz, se a magistrada que presidiu a colheita antecipada das provas estava em gozo de férias, quando da prolação da sentença, máxime porque diferentes os pedidos contidos nas ações principal e cautelar.

2. O entendimento assente nesta Corte, quanto a possibilidade jurídica do pedido, corresponde a inexistência de vedação explícita no ordenamento jurídico para o ajuizamento da demanda proposta.

3. A despeito da controvérsia em relação à matéria de fundo, o fato é que, para a hipótese em apreço, onde se pretende a declaração de união homoafetiva, não existe vedação legal para o prosseguimento do feito.

4. Os dispositivos legais limitam-se a estabelecer a possibilidade de união estável entre homem e mulher, dês que preencham as condições impostas pela lei, quais sejam, convivência pública, duradoura e contínua, sem, contudo, proibir a união entre dois homens ou duas mulheres. Poderia o legislador, caso desejasse, utilizar expressão restritiva, de modo a impedir que a união entre pessoas de idêntico sexo ficasse definitivamente excluída da abrangência legal. $\underline{\text { Contudo, }}$ assim não procedeu.

5. É possível, portanto, que o magistrado de primeiro grau entenda existir lacuna legislativa, uma vez que a matéria, conquanto derive de situação fática conhecida de todos, ainda não foi expressamente regulada.

6. Ao julgador é vedado eximir-se de prestar jurisdição sob o argumento de ausência de previsão legal. Admite-se, se for o caso, a integração mediante o uso da analogia, a fim de alcançar casos não expressamente contemplados, mas cuja essência coincida com outros tratados pelo legislador. 5. Recurso especial conhecido e provido" ${ }^{38}$ (grifou-se)

Da mesma forma o STJ, antes mesmo da decisão susoreferida, no ano de 2006 julgou Ação referente ao aproveitamento do plano de saúde entre o companheiro em uma união homoafetiva e manteve o entendimento da analogia de direitos da união estável em relação à homoafetiva, a saber:

"PROCESSO CIVIL E CIVIL - PREQUESTIONAMENTO - AUSÊNCIA SÚMULA 282/STF - UNIÃO HOMOAFETIVA - INSCRIÇÃO DE PARCEIRO

\footnotetext{
${ }^{38}$ STJ, $4^{\text {a }}$ Turma, REsp 820475 RJ 2006/0034525-4, Rel. Ministro Antônio De Pádua Ribeiro, julgado em 02/09/2008.
} 


\section{EM PLANO DE ASSISTÊNCIA MÉDICA - POSSIBILIDADE - DIVERGÊNCIA JURISPRUDENCIAL NÃO-CONFIGURADA. -}

Se o dispositivo legal supostamente violado não foi discutido na formação do acórdão, não se conhece do recurso especial, à míngua de prequestionamento.

- A relação homoafetiva gera direitos e, analogicamente à união estável, permite a inclusão do companheiro dependente em plano de assistência médica.

- O homossexual não é cidadão de segunda categoria. A opção ou condição sexual não diminui direitos e, muito menos, a dignidade da pessoa humana.

- Para configuração da divergência jurisprudencial é necessário confronto analítico, para evidenciar semelhança e simetria entre os arestos confrontados. Simples transcrição de ementas não basta." ${ }^{39}$ (grifou-se)

\subsubsection{Jurisprudência Contrária ao Reconhecimento da União Homoafetiva}

Assim como observamos no estudo jurisprudencial acima realizado um grande avanço no que diz respeito à dignidade da pessoa humana, igualdade e aceitação de uma realidade social, temos em nosso judiciário pátrio exemplos de retrocesso e disseminação do preconceito, seja por crenças pessoais motivadas por máscaras legais, seja por uma atenção quase que religiosa à letra fria da lei, ou quem sabe a grande dificuldade de olhar um pouco mais além, ou, como diz a máxima deveras utilizada nos Estados Unidos da América, think outside the box ${ }^{40}$.

Os julgados contrários ao reconhecimento da união homoafetiva e seu caráter familiar, teimavam em equiparar a união entre pessoas do mesmo sexo a uma sociedade de fato, como se tratasse de uma questão empresarial, uma união entre sócios com interesses comuns, estando seus direitos elencados na parte de obrigações em nosso Código Civil, sendo definida em seu art. $981^{41}$.

Sobre tal absurda comparação, Maria Berenice dias dispunha em sua obra de 2010 que:

\footnotetext{
${ }^{39}$ STJ, $4^{\text {a }}$ Turma, REsp 238715 RS 1999/0104282-8, Rel. Ministro Humberto Gomes De Barros, julgado em 06/03/2006.

${ }^{40}$ Tradução Livre - "pensar fora da caixa"

${ }^{41}$ Lei ${ }^{\circ} 10.406$, de 10 de janeiro de 2002 - art. 981. Celebram contrato de sociedade as pessoas que reciprocamente se obrigam a contribuir, com bens ou serviços, para o exercício de atividade econômica e a partilha, entre si, dos resultados.
} 
"Inclina-se a jurisprudência em reconhecer a existência de mera sociedade de fato (CC 981): Celebram contrato de sociedade as pessoas que reciprocamente se obrigam a contribuir, com bens e serviços, para o exercício de atividade econômica e a partilha, entre si, dos resultados. Visualiza-se exclusivamente um vínculo negocial, negando-se a relação afetiva que existe com as características de uma família. Nitidamente preconceituosa a analogia feita. Procura mudar a origem do vínculo, que é um elo de afetividade e não uma obrigação negocial de bens e serviços para o exercício de atividade econômica. Os resultados são desastrosos. Chamar as uniões de pessoas do mesmo sexo de sociedade de fato, e não de união estável, leva à sua inserção no direito obrigacional, com consequente alijamento do manto protetivo do direito das famílias, o que acaba por afastar os direitos sucessórios." ${ }^{42}$

Neste sentido, no ano de 2009, o Tribunal de Justiça do Distrito Federal e dos Territórios julgou Agravo de Instrumento em que fazia tal equiparação, a saber:

"AGRAVO DE INSTRUMENTO. CONSTITUCIONAL. CIVIL. PROCESSO CIVIL. COMPETÊNCIA PARA PROCESSAR E JULGAR AÇÃO DE RECONHECIMENTO E DISSOLUÇÃO DE RELAÇÃO HOMOAFETIVA. 1 A definição do juízo a que legalmente compete apreciar tais situações fáticas conflitivas, é exigência do princípio do juiz natural e constitui garantia inafastável do processo constitucional. 2 - Ausente regra jurídica expressa definidora do juízo responsável concretamente para conhecer relação jurídica controvertida decorrente de união entre pessoas do mesmo sexo, resta constatada a existência de lacuna do direito, o que torna premente a necessidade de integração do sistema normativo em vigor. Nos termos do que reza o Artigo $\underline{4}^{\circ}$ da Lei de Introdução ao Código Civil, a analogia é primeiro, entre os meios supletivos de lacuna, a que deve recorrer o magistrado. 3 - A analogia encontra fundamento na igualdade jurídica. $\mathrm{O}$ processo analógico constitui raciocínio baseado em razões relevantes de similitude. Na verificação do elemento de identidade entre casos semelhantes, deve o julgador destacar aspectos comuns, competindo-lhe também considerar na aplicação analógica o relevo que deve ser dados aos elementos diferenciais. 4 - A semelhança há de ser substancial, verdadeira, real. Não justificam o emprego da analogia meras semelhanças aparentes, afinidades formais ou identidades relativas a pontos secundários. 5 - Os institutos erigidos pelo legislador à condição de entidade familiar têm como elemento estrutural - requisito de existência, portanto - a dualidade de sexos. Assim dispõe a Declaração Universal dos Direitos Humanos em seu Preâmbulo e no item 1 do Artigo 16. No mesmo sentido a Constituição Brasileira promulgada em 05/outubro/1988 (Artigo $226 \mathrm{e}$ seus parágrafos), o Código Civil de 2002 e Lei n. ${ }^{\circ}$ 9.278, de 10/maio/1996, que regulamenta o parágrafo $3^{\circ}$ do Artigo $\underline{226}$ da $\underline{\mathrm{CF}}$. 6 - As entidades familiares, decorram de casamento ou de união estável ou se constituam em famílias monoparentais, têm como requisito de existência a diversidade de sexos. Logo, entre tais institutos, que se baseiam em união heterossexual, e as uniões homossexuais sobreleva profunda e fundamental diferença. A distinção existente quanto a elementos estruturais afasta a possibilidade de integração analógica que possibilite regulamentar a união homossexual com base em normas que integram o Direito de Família. 7 - As uniões homossexuais, considerando os requisitos

42 Dias, Maria Berenice. Manual de Direito das Famílias. $6^{\text {a }}$ ed. São Paulo: Revista dos Tribunais, 2010. p. 201. 
de existência que a caracterizam e que permitem identificá-las como parcerias civis, guardam similaridade com as sociedades de fato. Há entre elas elementos de identidade que se destacam e que justificam a aplicação da analogia. 8 - Entre parcerias civis e entidades familiares há fator de diferenciação que, em atenção ao princípio da igualdade substancial, torna constitucional, legal e legítima a definição do Juízo Cível como competente para processar e julgar demandas relativas a uniões homossexuais, que sujeitas estão ao conjunto das normas que integram o Direito das Obrigações. 9 - Agravo conhecido e provido para declarar a incompetência da Vara de Família e competente uma das Varas Cíveis da Circunscrição Especial Judiciária de Brasília,DF, para processar e julgar ação de reconhecimento e dissolução de relação homoafetiva. 10 Precedentes judiciais. Em especial, Conflitos de Competência n ${ }^{\circ}$ s. 20030020096835, 20050020054577 e 20070020104323 , Primeira Câmara Cível deste egrégio Tribunal." 43

À época, a grande discussão que chegava aos tribunais, assim como demonstrado no julgado acima, era a da competência para julgamento da dissolução de União Homoafetiva, ou seja, se deveria ser encaminhada para Vara Cível ou Vara de Família. Acontece que o mais comum, mesmo nos julgadores que claramente se mostravam adeptos ao reconhecimento da união homoafetiva como entidade familiar, era o encaminhamento para Vara Cível por falta de previsão legal, ou seja, por motivo de competência residual o argumento da parte de que a união possuía vínculo familiar ficava deveras enfraquecido. Isto, pois nem ao menos sua demanda seria julgada por uma Vara específica e qualificada para decidir questões referentes às famílias.

“APELAÇÃO CÍVEL. UNIÃO ESTÁVEL HOMOAFETIVA. INVIABILIDADE DE RECONHECIMENTO E DISSOLUÇÃO JUDICIAL POR AUSÊNCIA DE POSSIBILIDADE JURÍDICA DO PEDIDO. ENTIDADE FAMILIAR. NÃO CARACTERIZAÇÃO. INTELIGÊNCIA DOS ARTS. 226, § $3^{\circ}$, DA CONSTITUIÇÃO FEDERAL E 1.723 DO CÓDIGO CIVIL QUE TIPIFICAM A UNIÃO ESTÁVEL SOMENTE ENTRE HOMEM E MULHER. Ao contrário da legislação de alguns países, como é o caso, por exemplo, da Alemanha (LPartG), França, Suécia, Dinamarca ou da Holanda, país este que prevê mesmo o casamento homossexual, o direito brasileiro não prevê a união estável, e muito menos casamento, entre pessoas do mesmo sexo. Hipótese em que a interpretação judicial não tem o alcance de criar direito material, sob pena de invasão da esfera de competência do Poder Legislativo e violação do princípio republicano de separação dos poderes. APELAÇÃO DESPROVIDA." 44

\footnotetext{
${ }^{43}$ TJDFT, $5^{\text {a }}$ Turma Cível, Agravo de Instrumento 2008.00.2.012928-9, Rel. Diva Lucy Ibiapina, julgado em 18/03/2009.

${ }^{44}$ TJRS, $7^{\mathrm{a}}$ Câmara Cível, Apelação Cível No 70028838308 , Rel. José Conrado Kurtz de Souza, Julgado em 24/06/2009.
} 
No ano de 2006, o Tribunal de Justiça do Rio de janeiro julgou a questão do reconhecimento da união homoafetiva de maneira um tanto questionável. Tal decisão primeiramente reconheceu o afeto como fonte mais importante do direito de família e a norteadora das relações entre pessoas do mesmo sexo, mas, ao mesmo tempo não aceita a união homoafetiva como modalidade de família reconhecida pela ordem jurídica. Ocorreu que, no caso em tela, que se tratava de uma separação com pedido de alimentos, o julgador reconheceu que a união se formou a partir do afeto, mas, como seu término caracterizou uma quebra deste afeto, o desfazimento de tal união mostra-se incapaz de produzir os efeitos dentro do direito de família por supostamente ter deixado de ser uma família.

Ora, não faz o menor sentido os fundamentos criados pelo julgador no caso analisado. Uma separação entre homem e mulher comumente ocorre pela falta de afinidade, a quebra da relação de carinho, amor e afeto, mas nem por isso deixa de ser uma relação familiar capaz de produzir efeito após seu término. Não creio ser possível vislumbrar qualquer diferenciação em uma dissolução de União Estável e de uma União Homoafetiva, ambas encerraram uma relação afetuosa capaz de produzir direitos e deveres na medida de sua necessidade.

\title{
"RELACAO HOMOAFETIVA \\ ALIMENTOS \\ VARA DE FAMILIA \\ UNIAO ESTAVEL \\ INTERPRETACAO ANALOGICA \\ IMPOSSIBILIDADE
}

\begin{abstract}
Relação homoafetiva. Ação de alimentos. Competência. Vara de família. Analogia com a união estável. Impossibilidade. 1. As ações de alimentos cuja causa de pedir seja a relação homoafetiva, pretendendo equiparação por analogia com a união estável entre um homem e uma mulher, devem ser analisadas pelo juízo de família, considerando que não se está discutindo sociedade de fato. 2 . No mérito, a equiparação da relação homoafetiva com a instituição da família não se mostra admissível enquanto o texto constitucional, bem como o direito infraconstitucional (art. 1.723 do C. Civil), referirem expressamente que a entidade familiar é formada por um homem e uma mulher. 3. A única semelhança que de princípio se pode apontar da relação homossexual com a família nascida do relacionamento entre pessoas de sexos diferentes, é o afeto. Mas o afeto, ainda que seja reconhecido pela doutrina moderna do direito de família como o elemento mais importante da relação familiar, ainda não é fonte por si só de
\end{abstract}


obrigações. 4. Ainda assim, se a relação chegou ao fim, e portanto não há mais afeto, é impossível julgar a ação reconhecendo obrigação alimentar cuja fonte seria exatamente o afeto, inexistente a esta altura. Quando se desfaz um vínculo afetivo que resultou em família reconhecida pela ordem jurídica, como a decorrente do casamento ou da união estável, o que gera a continuidade do devedor de solidariedade é o vínculo jurídico, inexistente na relação homoafetiva. 5. Portanto, ainda que a relação entre as partes tenha se formado com base na liberdade e no afeto, hoje estão elas desavindas, sendo certo que não pode existir vínculo obrigacional sem fonte, que se resumem, na lição de Caio Mário, a duas: a vontade e a lei. ${ }^{, 45}$ (grifou-se)

\subsection{A ADI 4277}

\subsubsection{Breve Resumo}

O Egrégio Supremo Tribunal Federal julgou a Ação Direta de Inconstitucionalidade (ADI) 4277 junto da Arguição de Descumprimento de Preceito Fundamental (ADPF) 132. Assim, foi proferida decisão no sentido de reconhecer a união estável para casais do mesmo sexo, sendo as ações ajuizadas na Corte, respectivamente, pela Procuradoria-Geral da República e pelo governador do Rio de Janeiro, Sérgio Cabral. ${ }^{46}$

A ADI 4277 foi protocolada na Corte inicialmente como ADPF 178, buscando a declaração de reconhecimento da união entre pessoas do mesmo sexo como entidade familiar, e, consequentemente, que os mesmos direitos e deveres dos companheiros nas uniões estáveis fossem estendidos aos companheiros nas uniões entre pessoas do mesmo sexo. ${ }^{47}$

Já na Arguição de Descumprimento de Preceito Fundamental (ADPF) 132, o governo do Estado do Rio de Janeiro (RJ) alegou que o não reconhecimento da união homoafetiva contraria preceitos fundamentais como igualdade, liberdade (da qual decorre a autonomia da vontade) e o princípio da dignidade da pessoa humana, todos da Constituição Federal. Sendo assim, pediu que o STF aplicasse o regime jurídico das uniões

\footnotetext{
${ }^{45}$ TJRJ, $16^{\circ}$ Câmara Cível, Apelação Cível no 0004220-87.2006.8.19.0208 (2007.001.04634), Rel. Marcos Alcino A. Torres, julgado em 24/04/2007.

${ }^{46}$ Notícias STF: http://www.stf.jus.br/portal/cms/verNoticiaDetalhe.asp?idConteudo=178931

${ }^{47}$ Idem.
} 
estáveis, previsto no artigo 1.723 do Código Civil, analogicamente às uniões homoafetivas de funcionários públicos civis do Rio de Janeiro. ${ }^{48}$

Confira-se trecho do voto do Eminente Relator Ministro Ayres Britto:

\begin{abstract}
"Dando por suficiente a presente análise da Constituição, julgo, em caráter preliminar, parcialmente prejudicada a ADPF $\mathrm{n}^{\circ}$ 132-RJ, e, na parte remanescente, dela conheço como ação direta de inconstitucionalidade. No mérito, julgo procedentes as duas ações em causa. Pelo que dou ao art. 1.723 do Código Civil interpretação conforme à Constituição para dele excluir qualquer significado que impeça o reconhecimento da união contínua, pública e duradoura entre pessoas do mesmo sexo como "entidade familiar", entendida esta como sinônimo perfeito de "família". Reconhecimento que é de ser feito segundo as mesmas regras e com as mesmas conseqüências da união estável heteroafetiva". ${ }^{49}$ (grifou-se)
\end{abstract}

Sendo assim, o referido julgamento, ao dar amplitude à interpretação do artigo 1.723 do Código Civil, permitiu o reconhecimento legal da união homoafetiva como entidade familiar.

\title{
3.3.2 O Voto do llustríssimo Ministro Ayres Britto
}

A função institucional principal do Supremo Tribunal Federal é a de guardião constitucional, ou seja, a de não deixar que nosso texto legal de hierarquia mais elevada seja desrespeitado ou distorcido frente às questões que lhe são apresentadas. Sobre tal proteção, o jurista Felipe Derbli, em doutrina citada na própria ADI 4277, dispõe que:

\footnotetext{
"[...] os objetivos fundamentais da República, previstos nos quatro incisos do já mencionado art. $3 .^{\circ}$, dizem respeito à atuação do Poder Público na construção e na manutenção das liberdades fundamentais e na busca inescusável e ininterrupta de níveis minimamente aceitáveis de igualdade material, justiça social e solidariedade entre os indivíduos. Ora, é inevitável a conclusão de que está entre as finalidades do Estado Brasileiro, pelo menos implicitamente, a promocão dos direitos fundamentais, tarefa essa que incumbe a todos os entes da Federação, dentro dos limites de suas competências. E nem poderia ser de outra forma - afinal, a própria gênese do constitucionalismo associase à organização e racionalização do poder político para proteção dos direitos fundamentais.
}

\footnotetext{
${ }^{48}$ Idem.

49 STF, Ação Direta de Inconstitucionalidade 4.277, Min. Rel. Ayres Britto, julgado em 05/05/2011, p. 32 .
} 
Pois bem. Como visto acima, a promoção dos direitos fundamentais envolve, necessariamente, a atuação positiva do Poder Público não apenas na oferta de prestações materiais positivas, mas também no exercício de seus deveres de proteção, agindo no sentido de impedir a violação dos direitos fundamentais dos indivíduos ou de uma coletividade por terceiros. Cumpre ao Estado-membro, portanto, exercer tal mister e atuar comissivamente na defesa dos direitos fundamentais.

Nessa linha de raciocínio, se o Poder Público pode obstar à violação de direitos fundamentais por particulares ou por Estados estrangeiros, não parece haver qualquer impedimento a que um Estado-membro aja positivamente para proteger seus cidadãos da violação de direitos fundamentais perpetrada por outro ente da Federação, seja a União, outros Estados-membros ou Municípios. ${ }^{, 50}$ (grifou-se)

Sendo assim, o Eminente Ministro Ayres de Britto botou efetivamente em prática tal função do pretório excelso ao julgar a ADI 4277 com base nos princípios constitucionais maiores da Dignidade da pessoa humana e igualdade. Sendo tais princípios amplamente citados em seu voto, valendo citar o presente trecho em que dispõs acerca da dignidade da pessoa humana:

“Óbvio que, nessa altaneira posicão de direito fundamental e bem de personalidade, a preferência sexual se põe como direta emanação do princípio da "dignidade da pessoa humana" (inciso III do art. $1^{\circ}$ da CF), e, assim, poderoso fator de afirmacão e elevacãa pessoal. De auto-estima no mais elevado ponto da consciência. Auto-estima, de sua parte, a aplainar o mais abrangente caminho da felicidade, tal como positivamente normada desde a primeira declaração norte-americana de direitos humanos (Declaração de Direitos do Estado da Virgínia, de 16 de junho de 17768) e até hoje perpassante das declarações constitucionais do gênero. Afinal, se as pessoas de preferência heterossexual só podem se realizar ou ser felizes heterossexualmente, as de preferência homossexual seguem na mesma toada: só podem se realizar ou ser felizes homossexualmente. Ou "homoafetivamente", como hoje em dia mais e mais se fala, talvez para retratar o relevante fato de que o século XXI já se marca pela preponderância da afetividade sobre a biologicidade. Do afeto sobre o biológico, este último como realidade tão-somente mecânica ou automática, porque independente da vontade daquele que é posto no mundo como conseqüência da fecundação de um individualizado óvulo por um também individualizado espermatozóide." ${ }^{51}$ (grifou-se)

Perceba-se que o Ministro ainda cita o princípio da afetividade reconhececendo sua preponderancia frente a biologicidade. Dita afirmação

\footnotetext{
${ }^{50}$ DERBLI, Felipe (O papel do Estado membro no controle abstrato de constitucionalidade das leis em matéria de direitos fundamentais. In: VENTURA, Zênio; FAGÚNDEZ, Paulo (Org.). As Perspectivas da Advocacia Pública e a Nova Ordem Econômica. Florianópolis: OAB/SC Editora, 2006, v. , p. 133-154)

${ }^{51}$ STF, Ação Direta de Inconstitucionalidade 4.277, Min. Rel. Ayres Britto, julgado em 05/05/2011, p. 14
} 
de uma figura tão ilustre é um enorme marco para a evolução do direito das famílias. Esta representa uma quebra de uma vez por todas deste paradigma de que família é apenas composta por laços de sangue e união entre pessoas do sexo oposto, é um reconhecimento de uma realidade social que poderá ser precedente para maior proteção legislativa e jurisprudêncial para minorias segregadas.

Sobre a importância do reconhecimento pelo judiciário desta realidade social, Ayres Britto dispõe em seu voto que:

"Canetas de magistrados não são capazes de extinguir o preconceito, mas, num Estado Democrático de Direito, detêm o poder de determinar ao aparato estatal a atuação positiva na garantia da igualdade material entre os indivíduos e no combate ostensivo às discriminações odiosas. Esta Corte pode, aqui e agora, firmar posição histórica e tornar público e cogente que o Estado não será indiferente à discriminação em virtude da orientação sexual de cada um; ao revés, será o primeiro e maior opositor do preconceito aos homossexuais em qualquer de suas formas.

Com estas considerações, proceda-se ao exame do mérito propriamente dito, que as confirmará. É possível resumir a pretensão na seguinte fórmula: postula-se o reconhecimento da união entre pessoas do mesmo gênero como entidade familiar, do modo a gozar do mesmo reconhecimento que o Estado concede à união estável entre homem e mulher. Pede-se vênia, aqui, para que se discorra sobre dois conceitos fundamentais para a compreensão do caso: família e reconhecimento.

Como é cediço, o art. 226, caput, da Constituição de 1988 estabelece que a família, como base da sociedade, tem especial proteção do Estado. Trata-se de uma garantia institucional, destinada "a assegurar a permanência da instituição, embargando-lhe a eventual supressão ou mutilação e preservando invariavelmente o mínimo de substantividade ou essencialidade, a saber, aquele cerne que não deve ser atingido nem violado, [...]", sob pena de perecimento dessa instituição protegida."

Pouco mais a frente, o Ilustre Ministro cita doutrina do reconhecido doutrinador Gustavo Tepedino a respeito do novo papel da família em relação à Constituição Federal de 1988, a saber:

"Verifica-se, do exame dos arts. 226 a 230 da Constituição Federal, que o centro da tutela constitucional se desloca do casamento para as relações familiares dele (mas não unicamente dele) decorrentes; e que a milenar proteção da família como instituição, unidade de produção e reprodução dos valores culturais, éticos, religiosos e econômicos, dá lugar à tutela essencialmente funcionalizada à dignidade de seus membros, em particular no que concerne ao desenvolvimento da personalidade dos filhos. [...]

\footnotetext{
${ }^{52}$ STF, Ação Direta de Inconstitucionalidade 4.277, Min. Rel. Ayres Britto, julgado em 05/05/2011, p. 11.
} 
Assim sendo, a família, embora tenha ampliado, com a Carta de 1988, o seu prestígio constitucional, deixa de ter valor intrínseco, como instituição capaz de merecer tutela jurídica pelo simples fato de existir, passando a ser valorada de maneira instrumental, tutelada na medida em que - e somente na exata medida em que - se constitua em um núcleo intermediário de desenvolvimento da personalidade dos filhos e de promoção da dignidade dos seus integrantes." ${ }^{53}$ (grifou-se)

O eminente Ministro buscou em seu voto sempre deixar claro que a proteção constitucional da família não é cogente no sentido de limitar seu âmbito apenas às relações heterossexuais. Cita ainda o próprio $\S 4^{\circ}$ do art 226 da CF que reconhece as famílias monoparentais como merecedoras de proteção especial junto aos outros tipos de família. O julgador dá a entender a assertiva verdadeira de que não há como limitar o conceito de família, e, por isso mesmo, não foi papel nem houve intenção do constituinte da Magna Carta de 1988 em fazê-lo.

O Ministro ainda novamente menciona a observância dos princípios fundamentais da CF de 1988 como base para impossibilidade do "amesquinhamento" de tais princípios a favor de um rol taxativo de família, sendo incoerente qualquer texto neste sentido e passível de interpretação ampliativa pelos juristas, verbis:

"Tem-se, pois, que a proteção constitucional da família não se deu com o fito de se preservar, por si só, o tradicional modelo biparental, com pai, mãe e filhos. Prova disso é a expressa guarida, no $§ 4 .^{\circ}$ do art. 226, das famílias monoparentais, constituídas apenas pelo pai ou pela mãe e pelos descendentes; também não se questiona o reconhecimento, como entidade familiar inteira, dos casais que, por opção ou circunstâncias da vida, não têm filhos. Bem ao contrário, a Constituição de 1988 consagrou a família como instrumento de proteção da dignidade dos seus integrantes e do livre exercício de seus direitos fundamentais, de modo que, independentemente de sua formação quantitativa ou qualitativa -, serve o instituto como meio de desenvolvimento e garantia da existência livre e autônoma dos seus membros.

\footnotetext{
${ }^{53}$ TEPEDINO, Gustavo. (A Disciplina Civil-Constitucional das Relações Familiares. In Temas de Direito Civil. 3. edição. Rio de Janeiro: Renovar, 2004, p. 397-398.
} 
Dessa forma, o conceito constitucional pós-1988 de família despiu-se de materialidade e restringiu-se a aspectos meramente instrumentais, merecendo importância tão-somente naquilo que se propõe à protecão $e$ promoção dos direitos fundamentais dos indivíduos. Em síntese, não pode haver compreensão constitucionalmente adequada do conceito de família que aceite o amesquinhamento de direitos fundamentais." ${ }^{54}$ (grifou-se)

Em certo momento, no corpo do voto, o ministro faz um questionamento acerca da diferenciação entre a união entre duas pessoas de sexo oposto e de duas do mesmo sexo. Logo após, responde tais questionamentos com a óbvia conclusão de que não há a menor diferença entre as duas. Tanto um casal homossexual quanto um heterossexual compartilham da mesma relação de afeto e cumplicidade, qualquer afirmação contraria é mero preconceito e discriminação, sendo esses reprimidos com força de um dos objetivos fundamentais de nossa República Federativa, assim como previsto na Constituição Federal em seu art. $3^{\circ}$, $\mathrm{IV}^{55}$.

"Pois bem. O que distingue, do ponto de vista ontológico, as uniões estáveis, heteroafetivas, das uniões homoafetivas? Será impossível que duas pessoas do mesmo sexo não tenham entre si relação de afeto, suporte e assistência recíprocos? Que criem para si, em comunhão, projetos de vida duradoura em comum? Que se identifiquem, para si e para terceiros, como integrantes de uma célula única, inexoravelmente ligados?

A resposta a essas questões é uma só: Nada as distingue. Assim como companheiros heterossexuais, companheiros homossexuais ligam-se e apoiam-se emocional e financeiramente; vivem juntos as alegrias e dificuldades do dia-a-dia; projetam um futuro comum. Se, ontologicamente, união estável (heterossexual) e união (estável) homoafetiva são simétricas, não se pode considerar apenas a primeira como entidade familiar. Impõe-se, ao revés, entender que a união homoafetiva também se inclui no conceito constitucionalmente adequado de família, merecendo a mesma proteção do Estado de Direito que a união entre pessoas de sexos opostos.

Nesse diapasão, a distinção entre as uniões heterossexuais e as uniões homossexuais não resiste ao teste da isonomia. Para tanto, recorde-se, novamente, o magistério de ROBERT ALEXY (ob. cit., p. 395 e seguintes), para quem, inexistindo razão suficiente para o tratamento jurídico diferenciado, impõe-se o tratamento idêntico. Não há qualquer argumento razoável que ampare a diferenciação ou a exclusão das uniões homoafetivas do conceito constitucional de família. Deveras, os únicos fundamentos para a distinção entre as uniões heterossexuais e as uniões homossexuais, para fins

\footnotetext{
${ }^{54}$ STF, Ação Direta de Inconstitucionalidade 4.277, Min. Rel. Ayres Britto, julgado em 05/05/2011, p. 11.

${ }^{55}$ Constituição da República Federativa do Brasil de 1988. Art. $3^{\circ}$ Constituem objetivos fundamentais da República Federativa do Brasil: IV - promover o bem de todos, sem preconceitos de origem, raça, sexo, cor, idade e quaisquer outras formas de discriminação.
} 
de protecão jurídica sob o signo constitucional da família, são o preconceito e a intolerância, enfaticamente rechaçados pela Constituição já em seu preâmbulo (" $[. .$.$] a liberdade, a segurança, o bem-estar, o desenvolvimento, a$ igualdade e a justiça como valores supremos de uma sociedade fraterna, pluralista e sem preconceitos, [...]") e também no inciso IV do art. $3^{\circ}$ ("promover o bem de todos, sem preconceitos de origem, raça, sexo, cor, idade e quaisquer outras formas de discriminação") e, ainda, no art. $5^{\circ}$, caput ("Todos são iguais perante a lei, sem distinção de qualquer natureza, [...]")." ${ }^{, 56}$ (grifou-se)

Mais a frente em seu voto, o Ministro Ayres Britto aponta uma observação importante sobre a utilização do termo "família" pelo direito pátrio. O que o Autor indica é que o "substantivo" família previsto em nossa Carta Magna não possui um significado ortodoxo assim como muitos julgadores e estudiosos do direito crêem. Tal substantivo surge de forma mais ligada ao "coloquial", ou seja, aberto às práticas sociais e inovações que o tempo e a evolução cultural trouxeram e venham ainda a trazer futuramente. A saber:

"E assim é que, mais uma vez, a Constituição Federal não faz a menor diferenciação entre a família formalmente constituída e aquela existente ao rés dos fatos. Como também não distingue entre a família que se forma por sujeitos heteroafetivos e a que se constitui por pessoas de inclinação homoafetiva. Por isso que, sem nenhuma ginástica mental ou alquimia interpretativa, dá para compreender que a nossa Magna Carta não emprestou ao substantivo "família" nenhum significado ortodoxo ou da própria técnica jurídica. Recolheu-o com o sentido coloquial praticamente aberto que sempre portou como realidade do mundo do ser. Assim como dá para inferir que, quanto maior o número dos espaços doméstica e autonomamente estruturados, maior a possibilidade de efetiva colaboracão entre esses núcleos familiares, o Estado e a sociedade, na perspectiva do cumprimento de conjugados deveres que são funcões essenciais à plenificacão da cidadania, da dignidade da pessoa humana e dos valores sociais do trabalho. Isso numa projeção exógena ou extra muros domésticos, porque, endogenamente ou interna corporis, os beneficiários imediatos dessa multiplicação de unidades familiares são os seus originários formadores, parentes e agregados. Incluído nestas duas últimas categorias dos parentes e agregados o contingente das crianças, dos adolescentes e dos idosos. Também eles, crianças, adolescentes e idosos, tanto mais protegidos quanto partícipes dessa vida em comunhão que é, por natureza, a família. Sabido que lugar de crianças e adolescentes não é propriamente o orfanato, menos ainda a rua, a sarjeta, ou os guetos da prostituição infantil e do consumo de entorpecentes e drogas afins. Tanto quanto o espaço de vida ideal para os idosos não são os albergues ou asilos públicos, muito menos o relento ou os bancos de jardim em que levas e levas de seres humanos abandonados despejam suas últimas sobras de gente. mas o comunitário ambiente da própria família. Tudo conforme os expressos dizeres dos artigos 227 e 229 da Constituição, este último

56 STF, Ação Direta de Inconstitucionalidade 4.277, Min. Rel. Ayres Britto, julgado em 05/05/2011, p. 13 - 14. 
alusivo às pessoas idosas, e, aquele, pertinente às crianças e aos adolescentes." ${ }^{57}$ (grifou-se)

Como já observado pelos trechos apresentados acima, nada mais adequado do que o vocábulo genial para rotular o voto do Ilustríssimo Ministro Ayres de Britto no caso apresentado. De forma amplamente embasada e com uma redação impecável, o eminente julgador deixou na história do direito brasileiro um marco de proporções astronômicas a favor do progresso e igualdade.

O julgamento da ADI 4.277 é o primeiro grande passo para o tão batalhado reconhecimento da união homoafetiva e sua posterior conversão em casamento. Apesar desta segunda não ter sido diretamente regulada no voto em análise, somente o reconhecimento da união homoafetiva pela cúpula do judiciário brasileiro já é embasamento fortíssimo para futura regulamentação do casamento civil entre casais homossexuais. Pertinente aqui citar a célere frase do cantor e compositor Chico Buarque de Hollanda ${ }^{58}$ : "As pessoas têm medo das mudanças. Eu tenho medo que as coisas nunca mudem."

\section{4 - Possibilidade Do Casamento Civil Entre Homossexuais}

\subsection{1 - A Controvérsia}

Após a ADI 4277 ter equiparado a união homoafetiva com a união estável, surgiu nova questão no mundo jurídico que divide a doutrina, sendo esta a possibilidade do casamento civil entre pessoas do mesmo sexo. O voto do Ministro Ayres Britto deixou dúvidas sobre tal possibilidade na medida em que não se pronunciou claramente a respeito da questão, surgindo assim espaço para interpretações diversas.

\footnotetext{
57 STF, Ação Direta de Inconstitucionalidade 4.277, Min. Rel. Ayres Britto, julgado em 05/05/2011, p. 24- 25.

${ }^{58}$ Chico Buarque de Hollanda (19 de junho de 1944, Rio de Janeiro), músico brasileiro. É considerado um dos maiores nomes da MPB - Música Popular Brasileira.
} 
Quanto à dúvida gerada em relação ao casamento, merece igualmente destaque o fato de que o Ministro Cezar Peluso convocou o Poder Legislativo a assumir a tarefa de regulamentar o reconhecimento da união estável homoafetiva para casais do mesmo sexo, tendo reconhecido que o art. 226, $\S 3^{\circ}$ da Constituição Federal não exclui outras modalidades de entidades familiares, não se tratando de numerus clausus ${ }^{59}$. Porém, ao mesmo tempo em que reconheceu uma lacuna normativa no que se refere à regulamentação das uniões homoafetivas, considera as uniões entre pessoas do mesmo sexo apenas similares à união estável entre homem e mulher. ${ }^{60}$

No mesmo sentido, o Ministro Ricardo Lewandowski, apesar de votar pela procedência dos pedidos, faz clara distinção entre as uniões, tomando posição no sentido de que em certos casos há a exigência de diversidade sexual para seu exercício. Ora, o art. 1723 do CC, em tese, exige tal diversidade para configuração da união estável, tendo sido isto justamente alterado pela ADI 4277, carecendo de sentido o argumento do Ministro Lewandowski, a saber:

"Cuida-se, enfim, a meu juízo, de uma entidade familiar que, embora não esteja expressamente prevista no art. 226, precisa ter a sua existência reconhecida pelo Direito, tendo em conta a existência de uma lacuna legal que impede que o Estado, exercendo o indeclinável papel de protetor dos grupos minoritários, coloque sob seu amparo as relações afetivas públicas e duradouras que se formam entre pessoas do mesmo sexo.

Em suma, reconhecida a união homoafetiva como entidade familiar aplicam-se a ela as regras do instituto que lhe é mais próximo, qual seja, a união estável heterossexual, mas apenas nos aspectos em que são assemelhados, descartando-se aqueles que são próprios da relação entre pessoas de sexo distinto, segundo a vetusta máxima ubi eadem ratio ibi idem jus, que fundamenta o emprego da analogia no âmbito jurídico." ${ }^{61}$ (grifou-se).

Destarte, não há que se fazer qualquer diferenciação no âmbito legal entre a união estável e a união homoafetiva, tendo, a meu ver, o Ministro injustificadamente dado asas a mais dúvidas e embasamento mal fundado

\footnotetext{
59 "número fechado" em latim

${ }^{60} \mathrm{http}: / /$ www.stf.jus.br/portal/cms/verNoticiaDetalhe.asp?idConteudo=178946

${ }^{61}$ STF, Ação Direta de Inconstitucionalidade 4.277, Voto Min. Ricardo Lewandowski, julgado em 05/05/2011, p. 12.
} 
para os que se mostram contra o recebimento de uniões entre homossexuais como entidade familiar com direitos iguais.

Além disto, o Eminente Ministro Ayres Britto não entende que exista diretamente uma lacuna na Lei no que se refere às uniões homoafetivas, apenas um problema de interpretação que deveria ser sanado no momento do julgamento. Neste sentido, os direitos dos casais homossexuais seriam resguardados com maior celeridade e segurança, não sendo exigida, apesar de aconselhável, uma nova legislação para assegurá-los, apenas uma mudança de interpretação nacional sobre o tema.

Cabe trazer à colação assertiva do Ilustre Desembargador do Tribunal de Justiça de Pernambuco Jones de Figueirêdo Alves, que, no ano de 2002, em sede de debate acerca do Novo Código Civil, elucida sobre a atuação do juiz nas ditas "lacunas" do Direito de Família, deixando claro que cabe ao julgador decidir a respeito das novas questões referentes ao Livro IV da referida Lei que, ao longo do tempo, não se mostrarem claras:

"Nós nos defrontamos sempre com aquela perplexidade de a lei não ser bastante, porque ela não esgota o Direito. Aplicá-la com justiça é realizá-lo, mas, este Código traz, pelas suas cláusulas abertas, e normas carecidas de preenchimento, possibilitando que a própria lei, como estrutura normativa, realce a possibilidade desse mito da insuficiência ser desprezado e, consequentemente, garantir esta idéia de justiça axiológica.

O Direito de Família comete ao Juiz esta solução porque, na verdade, é no Direito de Família que se permeiam, pela subjetividade das relações interpessoais, pelos conflitos necessariamente não esgotados pela lei, a necessidade de o juiz, buscando valorar os ajustes conjugais ou a própria dificuldade operacional de aplicar a justiça ao caso concreto, ter ele o emprego destas cláusulas abertas. ${ }^{, 62}$ (grifou-se)

Diferente foi o entendimento do Ministro Gilmar Mendes, que se mostrou "preocupado" com a fundamentação do Voto do Ministro Ayres Britto. Com isso, reconheceu a união homoafetiva como entidade familiar, porém, não admite uma equiparação irrestrita e entende que há lacuna na

\footnotetext{
${ }^{62}$ ALVES, Jones de Figueirêdo - Livro IV - Do Direito de Família. In:, ALLEGRETTI, José Raul (Coord.). O Novo Código Civil, Rio de Janeiro: Tribunal de Justiça do Rio de Janeiro/CEDES Centro de Estudos e Debates - Editora Vozes, 2002, p. 98-99.
} 
Lei, não questão de interpretação capaz de superar a literalidade dos dispositivos, ipsis litteris:

\begin{abstract}
"Destaco que, em linhas gerais, estou de acordo com o pronunciamento do eminente Ministro Relator Ayres Britto quanto ao resultado deste julgamento, embora esteja a pontuar aqui uma série de preocupações e de divergências em relação à fundamentação de seu voto, ou pelo menos algumas explicações em relação à divergência de minha fundamentação.
\end{abstract}

É que, como já mencionei aqui, entendo existirem fundamentos jurídicos suficientes e expressos que autorizam o reconhecimento da união entre pessoas do mesmo sexo, não com base no texto legal (art. 1723 do Código Civil), nem com base na norma constitucional (art.226, § $3^{\circ}$ ), mas, sim, como decorrência de direitos de minorias, de direitos fundamentais básicos em nossa Constituição, do direito fundamental à liberdade de livre desenvolvimento da personalidade do indivíduo e da garantia de não discriminação dessa liberdade de opção (art. $5^{\circ}$, XLI, CF) - dentre outros explicitados em minha fundamentação - , os quais exigem um correspondente dever de proteção, por meio de um modelo de proteção institucional que até hoje não foi regulamentado pelo Congresso.

Nesse sentido, diferentemente do que expôs o Ministro Relator Ayres Britto - ao assentar que não haveria lacuna e que se trataria apenas de um tipo de interpretação que supera a literalidade do disposto no art. $226, \S 3^{\circ}$, da Constituição e conclui pela paridade de situações jurídicas - evidenciei o problema da constatação de uma lacuna valorativa ou axiológica quanto a um sistema de proteção da união homoafetiva, que, de certa forma, demanda uma solução provisória desta Corte, a partir da aplicacão, por exemplo, do dispositivo que trata da união estável entre homem e mulher, naquilo que for cabível, ou seja, em conformidade com a ideia da aplicação do pensamento do possível.

Até porque também tenho certo temor, que por dever e honestidade intelectual acho que devo explicitar, de que a equiparação pura e simples das relações, tendo em vista a complexidade do fenômeno social envolvido, pode nos preparar surpresas as mais diversas.

O exercício de imaginação institucional certamente nos estimula, mas, ao mesmo tempo, nos desanima, porque, quando fazemos os paradigmas e começamos a fazer as equiparações e as elucubrações - e sabemos como limitada é a nossa capacidade de imaginar os fatos -, certamente começamos a ver que pretender regular isso, como poderia talvez fazê-lo o legislador, é exacerbar demais essa nossa vocacão de legisladores positivos, para usar a expressão tradicional, com sério risco de nos perdermos, produzindo lacunas.

Apenas a título de exemplo, surgem desde logo diversas indagações. Qual seria a repercussão da decisão em relação às questões de filiação e da facilitação da conversão da união estável entre homem e mulher em casamento? Da mesma forma, no âmbito das relações entre o cidadão e o Estado, também há deveres e restrições a todos impostos, que deverão ser considerados. É o caso da aplicação das regras de vedação ao nepotismo, por exemplo. Em relação à legislação eleitoral, também se exige a adequação dessa nova realidade, como antes mencionei, para causas de inelegibilidade. O reconhecimento da 
união homoafetiva como instituição familiar equiparada para todos efeitos à união estável entre homem e mulher suscitaria ainda, a reflexão de sua repercussão no âmbito penal. Essas questões, mutatis mutandis, também afligem os próprios cultores do Direito Comparado. Eu me lembro de que estava em Portugal quando foi promulgada a lei do casamento de pessoas do mesmo sexo e lá houve a restrição quanto à adoção.

Sistemas diversos têm dado disciplinas específicas ao tema. Há outro recente exemplo: a lei recente da Argentina que aprovou o casamento de pessoas do mesmo sexo, que contém - claro que trata de todo tema do matrimônio - nada mais, nada menos do que quarenta e dois artigos.

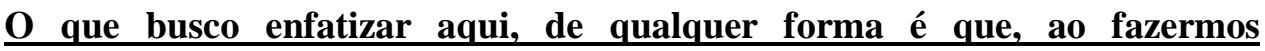
simplesmente uma equiparacão irrestrita, podemos acabar, também, por equiparar desde logo situacões que vão revelar diversidades. As escolhas aqui são de fato dramáticas e difíceis.

Por isso, neste momento, limito-me a reconhecer a existência da união entre pessoas do mesmo sexo, por fundamentos jurídicos próprios e distintos daqueles explicativos pelo ministro Ayres Britto e, com suporte na teoria do pensamento do possível, determinar a aplicação de um modelo de proteção semelhante - no caso, o que trata da união estável - naquilo que for cabível, nos termos da fundamentacão aqui apresentada, sem me pronunciar sobre outros desdobramentos." ${ }^{63}$ (grifou-se)

Oportuna se mostra, também, registrar a orientação, não unânime, adotada pelo Colendo STJ, no Recurso Especial no 1.183 .378 - RS (2010/0036663-8), da Relatoria do Ilmo. Ministro Luís Felipe Salomão, onde o douto julgador reconhece pelo texto da ADI 4277 o reconhecimento da união homoafetiva como entidade familiar e, considerando o casamento como uma proteção à família, não admite que este seja negado a nenhum tipo de família que opte por esta instituição, verbis:

"DIREITO DE FAMÍLIA. CASAMENTO CIVIL ENTRE PESSOAS DO MESMO SEXO (HOMOAFETIVO). INTERPRETAÇÃO DOS ARTS. $1.514,1.521,1.523,1.535$ e 1.565 DO CÓDIGO CIVIL DE 2002. INEXISTENCIA DE VEDAÇÃO EXPRESSA A QUE SE HABILITEM PARA O CASAMENTO PESSOAS DO MESMO SEXO. VEDAÇÃO IMPLÍCITA CONSTITUCIONALMENTE INACEITÁVELL. ORIENTAÇÃO PRINCIPIOLÓGICA CONFERIDA PELO STF NO JULGAMENTO DA ADPF N. 132/RJ E DA ADI N. 4.277/DF."

1. Embora criado pela Constituição Federal como guardião do direito infraconstitucional, no estado atual em que se encontra a evolução do direito privado, vigorante a fase histórica da constitucionalização do direito civil, não é possível ao STJ analisar as celeumas que lhe aportam "de costas" para a 63 STF, Ação Direta de Inconstitucionalidade 4.277, Voto Min. Gilmar Mendes, julgado em
05/05/2011, p. 51. 
Constituição Federal, sob pena de ser entregue ao jurisdicionado um direito desatualizado e sem lastro na Lei Maior. Vale dizer, o Superior Tribunal de Justiça, cumprindo sua missão de uniformizar o direito infraconstitucional, não pode conferir à lei uma interpretação que não seja constitucionalmente aceita.

2. O Supremo Tribunal Federal, no julgamento conjunto da ADPF n. 132/RJ e da ADI n. 4.277/DF, conferiu ao art. 1.723 do Código Civil de 2002 interpretação conforme à Constituição para dele excluir todo significado que impeça o reconhecimento da união contínua, pública e duradoura entre pessoas do mesmo sexo como entidade familiar, entendida esta como sinônimo perfeito de família .

3. Inaugura-se com a Constituição Federal de 1988 uma nova fase do direito de família e, consequentemente, do casamento, baseada na adoção de um explícito poliformismo familiar em que arranjos multifacetados são igualmente aptos a constituir esse núcleo doméstico chamado "família", recebendo todos eles a "especial proteção do Estado". Assim, é bem de ver que, em 1988, não houve uma recepção constitucional do conceito histórico de casamento, sempre considerado como via única para a constituição de família e, por vezes, um ambiente de subversão dos ora consagrados princípios da igualdade e da dignidade da pessoa humana. Agora, a concepção constitucional do casamento deve ser necessariamente plural, porque plurais também são as famílias e, ademais, não é ele, o casamento, o destinatário final da proteção do Estado, mas apenas o intermediário de um propósito maior, que é a proteção da pessoa humana em sua inalienável dignidade.

4. O pluralismo familiar engendrado pela Constituicãa - explicitamente reconhecido em precedentes tanto desta Corte quanto do STF - impede se pretenda afirmar que as famílias formadas por pares homoafetivos sejam menos dignas de proteção do Estado, se comparadas com aquelas apoiadas na tradição e formadas por casais heteroafetivos.

5. O que importa agora, sob a égide da Carta de 1988, é que essas famílias multiformes recebam efetivamente a "especial protecão do Estado", e é tão somente em razão desse desígnio de especial proteção que a lei deve facilitar a conversão da união estável em casamento, ciente o constituinte que, pelo casamento, o Estado melhor protege esse núcleo doméstico chamado família .

6. Com efeito, se é verdade que o casamento civil é a forma pela qual o Estado melhor protege a família, e sendo múltiplos os "arranjos" familiares reconhecidos pela Carta Magna, não há de ser negada essa via a nenhuma família que por ela optar, independentemente de orientação sexual dos partícipes, uma vez que as famílias constituídas por pares homoafetivos possuem os mesmos núcleos axiológicos daquelas constituídas por casais heteroafetivos, quais sejam, a dignidade das pessoas de seus membros e o afeto.

7. A igualdade e o tratamento isonômico supõem o direito a ser diferente, o direito à auto-afirmação e a um projeto de vida independente de tradições e ortodoxias. Em uma palavra: o direito à igualdade somente se realiza com plenitude se é garantido o direito à diferença . Conclusão diversa também não se mostra consentânea com um ordenamento constitucional que prevê o princípio do livre planejamento familiar ( $\S 7^{\circ}$ do art. 226). E é importante ressaltar, nesse ponto, que o planejamento familiar se faz presente tão logo haja a decisão de duas pessoas em se unir, com escopo de constituir família, e desde esse momento a 
Constituição lhes franqueia ampla liberdade de escolha pela forma em que se dará a união. 8. Os arts. 1.514, 1.521, 1.523, 1.535 e 1.565, todos do Código Civil de 2002, não vedam expressamente o casamento entre pessoas do mesmo sexo, $\mathrm{e}$ não há como se enxergar uma vedação implícita ao casamento homoafetivo sem afronta a caros princípios constitucionais, como o da igualdade, o da não discriminacão, o da dignidade da pessoa humana e os do pluralismo e livre planejamento familiar.

9. Não obstante a omissão legislativa sobre o tema, a maioria, mediante seus representantes eleitos, não poderia mesmo "democraticamente" decretar a perda de direitos civis da minoria pela qual eventualmente nutre alguma aversão. Nesse cenário, em regra é o Poder Judiciário - e não o Legislativo - que exerce um papel contramajoritário e protetivo de especialíssima importância, exatamente por não ser compromissado com as maiorias votantes, mas apenas com a lei e com a Constituição, sempre em vista a proteção dos direitos humanos fundamentais, sejam eles das minorias, sejam das maiorias. Dessa forma, ao contrário do que pensam os críticos, a democracia se fortalece, porquanto esta se reafirma como forma de governo, não das maiorias ocasionais, mas de todos.

10. Enquanto o Congresso Nacional, no caso brasileiro, na o assume, explicitamente, sua co-participação nesse processo constitucional de defesa e proteção dos socialmente vulneráveis, não pode o Poder Judiciário demitir-se desse mister, sob pena de aceitação tácita de um Estado que somente é "democrático" formalmente, sem que tal predicativo resista a uma mínima investigação acerca da universalização dos direitos civis.

11. Recurso especial provido". ${ }^{64}$ (grifou-se)

Tal decisum, contudo, como já alvitrado, não foi unânime, merecendo ser trazida à colação trecho do voto do Exmo. Senhor Ministro Raul Araújo que não se mostrou adepto aos argumentos dados pelo relator:

\begin{abstract}
"No julgamento do presente recurso especial, entendendo atuar sob efeito vinculante decorrente das decisões proferidas nas referidas ADI 4.277/DF e ADPF 132/RJ, esta colenda Corte de Justiça, na realidade, está interpretando indevidamente aqueles acórdãos e, possivelmente, ampliando o conteúdo daqueles julgados do Pretório Excelso naqueles feitos. Ali, reconheceu-se a possibilidade de haver união estável entre duas pessoas do mesmo sexo, enquanto aqui se está deliberando acerca de um outro instituto, o casamento
\end{abstract}

civil, o qual não é um mero consectário ou apêndice (acessório) de uma união estável. O tradicional e milenar casamento civil e a inovadora e recente união estável são institutos jurídicos independentes, com previsões constitucionais e regramentos próprios.

Ter-se-ia observância de efeito vinculante caso o presente recurso especial tratasse de ação cujo mérito discutisse algum consectário de união estável homoafetiva, como, por exemplo, o regime de bens dessa união, a possibilidade de os companheiros fazerem em conjunto a declaração de

\footnotetext{
${ }^{64}$ STJ, 4 ${ }^{\mathrm{a}}$ Turma, REsp 1.183.378 - RS (2010/0036663-8), Rel. Ministro Luís Felipe Salomão, julgado em 25/10/2011.
} 
ajuste anual de imposto de renda, o pagamento de pensão alimentícia, enfim, qualquer tema ligado a efeito ou atributo da união estável homoafetiva reconhecida pelo Supremo Tribunal. Mas não é isso. O que se tem aqui é a discussão em torno da possibilidade de haver casamento civil entre duas pessoas de mesmo sexo. E sobre esse tema, parece, a egrégia Corte Suprema nada deliberou, por ocasião do julgamento daquelas ações constitucionais". ${ }^{65}$ (grifou-se)

Em tal ordem de ideias, com base nos entendimentos que podem ser retirados dos votos dos Ministros Ricardo Lewandowski e Gilmar Mendes, bem como ainda do Ministro Cesar Peluzo, este ao afirmar que "há similitude e não igualdade factual em relação à união estável entre homem e mulher e a união entre pessoas do mesmo sexo", e por derradeiro do Ministro Raul Araújo do STJ, supra mencionado, este último no sentido de que o casamento civil e a união estável são institutos jurídicos independentes, com previsões constitucionais e regramentos próprios, não havendo efeito vinculante das decisões do E. STF no julgamento da ADPF $n^{o} 132 / \mathrm{RJ}$ e da ADI $n^{\circ}$ 4.277/DF na questão do casamento civil entre homossexuais, tal extensão interpretativa resta prejudicada.

Tal conclusão se extrai na utilização expressa dos gêneros distintos, homem e mulher/ prevista no artigo 226, $\S 3^{\circ}$, da Constituição Federal conforme o qual os direitos e deveres referentes à sociedade conjugal são exercidos igualmente pelo homem e pela mulher, o que vem a ratificar a suposta exigência Constitucional de diversidade de sexo dos nubentes.

A conferir, também, o artigo 1.514 do Código Civil que estabelece: O casamento se realiza no momento em que o homem e a mulher manifestam, perante o juiz, a sua vontade de estabelecer vínculo conjugal, e o juiz os declara casados. Mais adiante, no artigo 1.517: O homem e a mulher com dezesseis anos podem casar, exigindo-se autorização de ambos os pais, ou de seus representantes legais, enquanto não atingida a maioridade civil.

\footnotetext{
${ }^{65}$ STJ, 4 ${ }^{\text {a }}$ Turma, REsp 1.183.378 - RS (2010/0036663-8), Voto vencido. Ministro Raul Araújo, julgado em 25/10/2011.
} 
Diante do exposto temos que, para certos juristas, a equiparação entre as uniões não é por completa, devendo ser aplicados ao pé da letra os demais dispositivos que "exigem" homem e mulher. Interpretação essa que tudo indica que será extinta pelo rumo que o judiciário e legislativo tem buscado tomar em relação aos direitos dos homossexuais. Sobre o tema, cabe citar a brilhante assertiva da ilustre doutrinadora Maria Berenice Dias:

"A tendência do juiz é arvorar-se como paladino da moral e guardião dos bons costumes, ungindo-se da função de punir com a pena de banimento de direitos todos os que fogem dos padrões "normais". São sonegados direitos a quem ousa viver fora do formato convencional. Sob o fundamento de inexistir lei, tudo o que o magistrado pessoalmente não aceita para si, ou que se afasta de suas convicções religiosas, acaba excluído da órbita da juridicidade. Olvida que se vive em um país laico, sob o império dos princípios constitucionais que consagram o respeito à dignidade humana. Ao invés de a Justiça cumprir seu mister de fazer justiça, muitas vezes deixa de colocar ao seu abrigo todos os cidadãos, sob o fundamento simplista de inexistir norma legal que, modo expresso, assegure direito a quem é considerado "torto"

Essa visão extremamente limitada da função de julgar, de dar a cada um o que é seu, de garantir a todos o bem da vida que lhe garanta a vida, faz com que seja negado amparo a situações que o legislador, por puro preconceito, não tem coragem de regulamentar." ${ }^{66}$

\subsection{2 - Argumentos Favoráveis}

O ministro Ayres Britto, em seu brilhante voto, equiparou por completo a união estável e a união homoafetiva, reconhecendo que é apenas uma questão de interpretação do $\S 3^{\circ}$ do art. 226 da Constituição Federal e do art. 1723 do CC. Ora, se um dispositivo constitucional pode ser interpretado de forma não literal ao entender que a união estável não precisa ser apenas entre homem e mulher para produzir efeitos, que sentido teria manter a interpretação preconceituosa e atrasada dos demais dispositivos referentes ao casamento civil dispostos em Lei ordinária?

Além disto, o próprio $§ 3^{\circ}$ do art. 226 da CF/88 prevê que a Lei deve facilitar a conversão da união estável em casamento. Assim vejamos, sendo a união homoafetiva equiparada à união estável, sendo o texto do próprio $\S$

66 DIAS, Maria Berenice. União Homoafetiva - O preconceito e a Justiça - $5^{\mathrm{a}}$ ed. Rio de Janeiro: Revista dos Tribunais, 2012. p. 15-16. 
$3^{\circ}$ do art. 226 da $\mathrm{CF} / 88$ interpretado ampliativamente no sentido de reconhecer sua validade para casais do mesmo sexo, qual o sentido em ignorar tal dever de facilitação a favor de uma interpretação reducionista do texto legal do Código Civil no que diz respeito ao casamento?

Como visto acima, os julgados analisados dão margem a única forma que teriam de manter a posição preconceituosa de diferenciação entre uniões, ou seja, o não reconhecimento da totalidade da equiparação entre as uniões estável e homoafetiva. Ao permitir tal distinção, os julgadores abriram espaço para discussões que só vão atrasar, mas não parar, o progresso que havia sido feito a favor da comunidade GLS ${ }^{67}$.

Mesmo diante de tais argumentos, o voto do Ilustre Ministro do STJ Luís Felipe Salomão, susoreferido, é categórico ao reconhecer a união homoafetiva como entidade familiar e, portanto, merecedora de proteção em todos os sentidos inclusive pelo casamento. Neste raciocínio, mesmo aos que creem que não há equiparação total à união estável, a união homoafetiva, por seu caráter conjugal familiar, teria de forma autônoma direito de ser convertida em casamento civil.

\section{5 - A Resolução CNJ no 175 e seu Recebimento}

Devido à divergência interpretativa da ADI 4277, assim como já demonstrado mais acima, certos obstáculos vieram a ocorrer em tentativas de casais do mesmo sexo de contrair matrimônio nos moldes do casamento civil. O jornal O Globo, em seu website, chegou até a realizar matéria referente à recusa de juízes de registro civil em reconhecer o casamento homossexual, em especial o Juiz Luiz Henrique Oliveira Marques do Rio de janeiro que em reportagem, quando questionado sobre sua motivação para tais recusas, expôs que: "Meus argumentos são jurídicos. $\mathrm{O}$ nosso ordenamento jurídico não admite o casamento de pessoas do mesmo sexo, pura e simplesmente. Não tem nada a ver com religião. Eu sou juiz, e um

\footnotetext{
${ }^{67}$ Gays, lésbicas e simpatizantes.
} 
juiz precisa se abstrair desses outros conceitos o máximo que puder para

julgar. Mesmo se eu adotasse uma religião que fosse contrária, eu devo julgar perante a lei." 68

Diante disto, o Conselho Nacional de Justiça, em 14 de maio de 2013, emitiu a Resolução $n^{\circ} 175$ em que regulamentava o casamento homossexual com base na decisão da ADI 4277, a saber:

\section{"Resolução n" 175, de 14 de maio de 2013}

Dispõe sobre a habilitação, celebração de casamento civil, ou de conversão de união estável em casamento, entre pessoas de mesmo sexo.

O PRESIDENTE DO CONSELHO NACIONAL DE JUSTIÇA, no uso de suas atribuições constitucionais e regimentais,

CONSIDERANDO a decisão do plenário do Conselho Nacional de Justiça, tomada no julgamento do Ato Normativo no 0002626-65.2013.2.00.0000, na 169 Sessão Ordinária, realizada em 14 de maio de 2013;

CONSIDERANDO que o Supremo Tribunal Federal, nos acórdãos prolatados em julgamento da ADPF 132/RJ e da ADI 4277/DF, reconheceu a inconstitucionalidade de distinção de tratamento legal às uniões estáveis constituídas por pessoas de mesmo sexo;

CONSIDERANDO que as referidas decisões foram proferidas com eficácia vinculante à administração pública e aos demais órgãos do Poder Judiciário;

CONSIDERANDO que o Superior Tribunal de Justiça, em julgamento do RESP 1.183.378/RS, decidiu inexistir óbices legais à celebração de casamento entre pessoas de mesmo sexo;

CONSIDERANDO a competência do Conselho Nacional de Justiça, prevista no art. 103-B, da Constituição Federal de 1988;

\section{RESOLVE:}

Art. $1^{\circ}$ É vedada às autoridades competentes a recusa de habilitação, celebração de casamento civil ou de conversão de união estável em casamento entre pessoas de mesmo sexo.

Art. $2^{\circ}$ A recusa prevista no artigo $1^{\circ}$ implicará a imediata comunicação ao respectivo juiz corregedor para as providências cabíveis.

Art. $3^{\circ}$ Esta resolução entra em vigor na data de sua publicação.

\section{Ministro Joaquim Barbosa"}

\footnotetext{
${ }^{68}$ http://oglobo.globo.com/rio/casamento-gay-uma-uniao-ainda-dificil-no-rio-4976208
} 
Por mais nobre e louvável que seja a Resolução susoreferida, sua aplicação continua prejudicada tendo em vista a discussão gerada acerca da competência do CNJ para decidir tal questão, com o argumento de que o mesmo estaria extrapolando sua competência e alcançando a do Poder Legislativo.

O Conselho Nacional de Justiça (CNJ) foi criado e instituído pela Emenda Constitucional $n^{\circ} 45 / 2004$, sendo composto por 15 Conselheiros e presidido pelo Presidente do Supremo Tribunal Federal, com assento no artigo 103-B da Constituição Federal.

Conforme disposto no caput do parágrafo $4^{\circ}$. do citado artigo 103-B da Constituição Federal ao CNJ "compete o controle da atuação administrativa e financeira do Poder Judiciário além de fiscalizar o cumprimento dos deveres funcionais dos juízes, cabendo-lhe, além de outras atribuições que lhe forem conferidas pelo Estatuto da Magistratura”.

Em cotejo às atribuições do $\mathrm{CNJ}$ destaca-se prima facie, competirlhe zelar pela autonomia do Poder Judiciário e pelo cumprimento do Estatuto da Magistratura, podendo expedir atos regulamentares, no âmbito de sua competência, ou recomendar providências (inciso I, § $4^{\circ}$. artigo 103B da Constituição Federal).

A seguir vê-se competir-lhe zelar pela observância do artigo 37 da Constituição Federal e apreciar, de ofício ou mediante provocação, a legalidade dos atos administrativos praticados por membros ou órgãos do Poder Judiciário, podendo desconstituí-los, revê-los ou fixar prazo para que se adotem as providências necessárias ao exato cumprimento da lei, sem prejuízo da competência do Tribunal de Contas da União (inciso II, $\S 4^{\circ}$. artigo 103-B da Constituição Federal).

Prosseguindo a leitura dos demais incisos, VII ao total, depreende-se sem rebuços de dúvidas ser o CNJ órgão administrativo, caracterização que 
se mostra imprescindível e essencial à análise de sua atividade e atuação perante os demais órgãos do Poder Judiciário.

Em tal ordem de ideias, vêem-se no texto constitucional expressões como "expedir atos regulamentares" e "apreciar, de ofício ou mediante provocação, a legalidade dos atos administrativos praticados por membros ou órgãos do Poder Judiciário" e ainda, adotar "providências necessárias ao exato cumprimento da lei”.

Diante disto, o Partido Social Cristão (PSC), certamente por questões de conviç̧ão religiosa, ajuizou Mandado de Segurança (MS 32077) no Supremo Tribunal Federal (STF) contra ato da presidência do Conselho Nacional de Justiça (CNJ) consistente na edição da Resolução 175, de 14 de maio de 2013, que veda "às autoridades competentes a recusa de habilitação, celebração de casamento civil ou de conversão da união estável em casamento entre pessoas do mesmo sexo"69.

Segundo o PSC, ao dispor sobre a questão, o CNJ violou direito líquido e certo de todos os seus filiados, especialmente de seus 19 deputados federais e um senador, de discutir e votar a matéria no âmbito do Poder Legislativo. O partido pediu liminar para suspender os efeitos da resolução e, no mérito, pediu que sua vigência fosse suspensa até que o Congresso Nacional delibere sobre a questão. ${ }^{70}$

O mandamus foi extinto sem exame do mérito com fincas na Súmula $\mathrm{n}^{\circ} 266$ do STF. Súmula nº 266. "Não cabe mandado de segurança contra lei em tese", decisão monocrática da lavra do Ministro LUIZ FUX assim ementada:

"DIREITO CONSTITUCIONAL. DIREITO CIVIL. MANDADO DE SEGURANÇA. PARTIDO POLÍTICO COM REPRESENTAÇÃO NO CONGRESSO NACIONAL. LEGITIMIDADE "AD CAUSAM" RECONHECIDA. RESOLUÇÃO $\mathrm{N}^{\circ} 175$ DO CNJ. VEDAÇÃO ÀS

\footnotetext{
${ }^{69} \mathrm{http}: / /$ www.stf.jus.br/portal/cms/verNoticiaDetalhe.asp?idConteudo=239066

${ }^{70}$ Idem
} 
AUTORIDADES COMPETENTES DE HABILITAÇÃO, CELEBRAÇÃO DE CASAMENTO CIVIL OU CONVERSÃO DA UNIÃO ESTÁVEL EM CASAMENTO. ATO NORMATIVO DOTADO DE GENERALIDADE, ABSTRAÇÃO E IMPESSOALIDADE. INADEQUAÇÃO DA VIA ELEITA (SÚMULA $\mathrm{N}^{\circ} 266$ DO STF). CONSTITUCIONALIDADE DO ATO IMPUGNADO. COMPETÊNCIA NORMATIVA DO CNJ RECONHECIDA

NA ADC $N^{\circ} 12$, REL. MIN. AYRES BRITTO. POSSIBILIDADE DE O CNJ FORMULAR EX ANTE E IN ABSTRACTO JUÍZOS ACERCA DA VALIDADE DE DADA SITUAÇÃO FÁTICA. MANDADO DE SEGURANÇA EXTINTO SEM RESOLUÇÃO DE MÉRITO." 71

Extrai-se a v. decisão monocrática:

"De fato, a referida Resolução, à semelhança das espécies normativas primárias, retira seu fundamento de validade diretamente da Lei Fundamental, e não de outro ato normativo que a tenha precedido. Em seus consideranda, a Resolução $\mathrm{CNJ}^{\circ}$ 175/2013 claramente alude ao seu fundamento: as decisões proferidas por esta Suprema Corte, nos autos da ADPF n ${ }^{\circ}$ 132/RJ e da ADI n ${ }^{\circ}$ 4277/DF, ambas de relatoria do Min. Ayres Britto, e a decisão proferida nos autos do REsp $n^{\circ}$ 1.183.378/RS, Rel. Min. Luis Felipe Salomão. Em todos os casos, a controvérsia gravitou em torno do sentido e alcance da exegese do art. 226, $\S 3^{\circ}$, da Constituição da República. É inobjetável, diante dessa constatação, que a Resolução $n^{0}$ 175/2013, por buscar seu fundamento de validade no art. 226, $\S^{\circ}$, da $\mathbf{C R F B} / \mathbf{8 8}$, na interpretação que lhe foi conferida pelo Supremo Tribunal Federal e pelo Superior Tribunal de Justiça, reveste-se de generalidade, autonomia, abstração e impessoalidade. Exatamente porque ostenta tais apanágios, a Resolução n" 175/2013 qualifica-se como "lei em tese”, razão por que não se submete ao controle jurisdicional pela via do mandado de segurança, atraindo, por isso, a incidência, na espécie, da vedação contida na Súmula $\mathrm{n}^{\circ} 266$ desta Corte (STF. Súmula n ${ }^{\circ} 266$. "Não cabe mandado de segurança contra lei em tese"). ${ }^{72}$ (grifou-se)

Em sua v. decisão o Eminente Ministro Relator, apesar de decidir pelo não cabimento do mandamus, extinguindo-o sem exame do mérito, discorreu sobre o meritum causae da forma seguinte:

\begin{abstract}
"As alegações do Impetrante neste writ podem ser resumidas no seguinte questionamento: ao regular, por meio da Resolução $n^{\circ}$ 175/2013, a habilitação, celebração de casamento civil ou de conversão de união estável em casamento entre pessoas de mesmo sexo, o Presidente do Conselho Nacional de Justiça teria exorbitado de suas competências constitucionais, adentrando em campo reservado à lei, em flagrante ultraje ao equilíbrio entre os Poderes, ou, ao revés, atuou dentro de seu espaço de conformação legislativa conferido ao CNJ pelo constituinte derivado, quando da promulgação da $E C n^{\circ} 45 / 2004$ ?
\end{abstract}

\footnotetext{
${ }^{71}$ STF, Medida Cautelar em Mandado de Segurança 32.077, Min. Rel. Luiz Fux, julgado em 28/05/2013.

${ }^{72}$ STF, Medida Cautelar em Mandado de Segurança 32.077, Min. Rel. Luiz Fux, julgado em 28/05/2013.
} 
Todavia, entendo, neste juízo liminar, que o fumus milita em favor da possibilidade de o $\mathrm{CNJ}$ regular a matéria em comento.

Com efeito, a discussão acerca do poder normativo do Conselho Nacional de Justiça já foi objeto de apreciação pelo Plenário da Corte, nos autos da ADC n ${ }^{\circ}$ 12/DF. Rel. Min. Ayres Britto. Não se pretende aqui retomar tal discussão, mas apenas transladar as principais premissas e conclusões indispensáveis ao deslinde da controvérsia posta nos autos.

Naquela assentada, o Tribunal, reconhecendo a constitucionalidade da Resolução CNJ no 07, que proscrevia a prática cognominada de "nepotismo", consignou expressamente a competência do Conselho Nacional de Justiça para editar atos normativos primários. Segundo a Corte, tal prerrogativa fora genericamente atribuída pelo constituinte derivado ao CNJ, ex vi do art.103-B, § $4^{\circ}$, II, inserido pela EC $n^{\circ} 45 / 2004$, e que a vedação ao nepotismo, contida na Resolução atacada, densificava os princípios da moralidade, impessoalidade, igualdade e eficiência (CRFB/88, art. 37, caput). Afastou-se, desse modo, qualquer antinomia entre os modelos normativo constitucional e infraconstitucional. A competência normativa do Conselho Nacional de Justiça foi precisamente explicitada no voto do relator da $\mathrm{ADC} \mathrm{n} \mathrm{n}^{\circ}$ 12, Min. Ayres Britto.

...em ambos os casos, o CNJ editou as referidas normas (Resolução $\mathrm{n}^{\circ} 7 / 2005$ e Resolução $\mathrm{n}^{\circ}$ 175/2013) com fundamento direto em parâmetros erigidos constitucionalmente.

Como visto, a Resolução $\mathrm{CNJ} \mathrm{n}^{\circ}$ 07/2005, ancorada no art. 103-B, §4 ${ }^{\circ}$, II, daCRFB/88, impôs uma vedação à prática de nepotismo dentro da administração do Poder Judiciário a partir dos princípios insculpidos no art. 37, caput, da

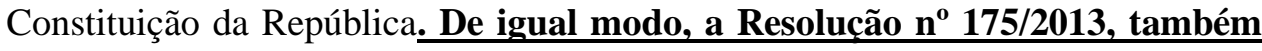
com esteio no art. 103-B da Constituição, interditou a recusa, por parte das autoridades competentes, da habilitação, celebracão de casamento civil ou de conversão de união estável em casamento entre pessoas de mesmo sexo, atendendo aos fins colimados pela CRFB/88, notadamente após o julgamento da ADPF n $n^{\circ} 132 / R J$ e da ADI n $n^{\circ} 4277 / D F$.

Deveras, antes de constituir ofensa, a atuação do Conselho Nacional de Justiça se coaduna com as suas competências outorgadas pelo precitado art. 103B, $\S 4^{\circ}$, II da Constituição de 1988. Eis o teor da norma

constitucional, verbis:

“Art. 103-B (...)

II. zelar pela observância do art. 37 e apreciar, de ofício ou mediante provocação, a legalidade dos atos administrativos praticados por membros ou órgãos do Poder Judiciário, podendo desconstituí-los, revê-los ou fixar prazo para que se adotem as providências necessárias ao exato cumprimento da lei, sem prejuízo da competência do Tribunal de Contas da União;" 
Da leitura do indigitado preceito, extraem-se duas competências: (i) zelar pela observância do art. 37 e (ii) proceder à apreciação da legalidade dos atos administrativos praticados por membros ou órgãos do Poder Judiciário, podendo, inclusive, desconstituir tais atos ou fixar prazo para que se adotem, in concrecto, as providências necessárias à estrita observância da lei. Interessa, no caso sub examine, a segunda atribuição.

Ora, se incumbe ao Conselho Nacional de Justiça proceder, nos casos concretos, a tal avaliação (i.e., desconstituir os atos editados por órgãos e membros do Poder Judiciário, revê-los ou fixar prazo para que se adotem providências necessárias ao estrito cumprimento da lei), é inelutável a sua competência para regular in abstracto tais assuntos, antecipando, por meio de Resoluções, o seu juízo acerca da validade ou invalidade de uma dada situação fática. Nesse sentido, assinala Sérgio Ferraz que "aquilo que o administrador pode ordenar ou proibir em um caso isolado, pode ordenar ou proibir em forma geral, para todos os demais casos similares." (FERRAZ, Sérgio. Regulamento. In.: Três estudos de Direito Administrativo, 1977, p. 107)." ${ }^{73}$ (grifou-se)

O Ministro Fux entende que o CNJ tinha dever de agir nesta situação tendo em vista a inobservância de uma decisão do STF que não estava sendo cumprida pelos magistrados competentes. Ocorre que, assim como defendido no presente trabalho, o Ministro interpreta a questão do casamento civil como incidental ao reconhecimento da união homoafetiva, devendo apenas ser regulada para seu fiel cumprimento, e não legislada.

As considerações acerca do mérito da impetração, repita-se extinta sem exame do mérito, no entender dos que são contrários ao casamento civil entre homossexuais, afronta não apenas o regime democrático, concedendo poder de legislar a órgão administrativo do poder judiciário, acerca de tema com sede Constitucional como é o casamento (artigo 226), como também afronta a competência privativa da União para legislar sobre Direito Civil, artigo 22 inciso I da CF.

Ocorre que, assim como disposto pelo Ministro, o CNJ não está agregando à sua competência poder legiferante, apenas sua função de desconstituir os atos editados por órgãos e membros do Poder Judiciário, revê-los ou fixar prazo para que se adotem providências necessárias ao

\footnotetext{
73 STF, Medida Cautelar em Mandado de Segurança 32.077, Min. Rel. Luiz Fux, julgado em 28/05/2013.
} 
estrito cumprimento da lei, tendo em vista a divergência de interpretação que vinha ocorrendo em razão da ADI 4277.

Diante disto, percebe-se que, diferente do que foi intencionado pela Resolução 175 do CNJ, somente mais dúvidas foram geradas a partir de tal medida. Apesar de já ser um grande avanço em direção à igualdade, certamente não foi o ponto final ao passo que a maioria dos adeptos à proibição do casamento civil entre pessoas do mesmo sexo poderão manter sua interpretação acerca da ADI 4277 com a adição de não reconhecer o $\mathrm{CNJ}$ como competente para regular tal questão. 


\section{CONCLUSÃO}

Destarte, mesmo com tanta contenda surgida a partir da questão inicial do reconhecimento da união homoafetiva como entidade familiar, o direito homoafetivo vem tomando lentamente seu lugar em nosso ordenamento jurídico. Não me espantaria se logo fosse editada legislação estabelecendo proteção integral das regras do direito das famílias para casais do mesmo sexo, nos moldes do projeto do Estatuto das Famílias mencionado anteriormente.

Além da maior proteção que a Lei cede às famílias e ao casamento, também há o que se pensar sobre o aspecto social do casamento homoafetivo. Muitas pessoas têm o comum sonho em se casar, se imaginam desde crianças em um altar com a pessoa que escolheu passar o resto da vida junto, faz questão de ter registrado em órgão competente sua condição de esposa ou marido. Que poder e sobre qual fundamento a sociedade tem para impedir a concretização de um sonho que não diz respeito a mais ninguém além da própria pessoa e seu (sua) companheiro (a)?

Nosso ordenamento jurídico não foi criado com o intuito de prejudicar as minorias somente por ser um alvo fácil, muito pelo contrário. A legislação de um estado democrático tem como função a proteção de quem mais precisa, ou seja, de quem não tem força sozinho para se levantar contra as massas e fazer valer seus direitos. Portanto, assim como o consumidor $^{74}$, a mulher ${ }^{75}$, o idoso ${ }^{76} \mathrm{e}$ as famílias já "reconhecidas" possuem proteção especial em certas questões pelo direito pátrio, assim também devem ter os casais do mesmo sexo que sofrem com o preconceito ao tentarem buscar seu reconhecimento legal como cônjuge e entidade familiar.

\footnotetext{
${ }_{75}^{74}$ Lei n $\mathrm{n}^{\mathrm{o}}$ 8.078, de 11 de setembro de 1990 - Código de Defesa do Consumidor

${ }^{75}$ Lei no 11.340 , de 07 de agosto de 2006 - Lei Maria da Penha

${ }^{76}$ Lei n $^{\circ} 10.741$, de $1^{\circ}$ de outubro de 2003 - Estatuto do Idoso
} 
Após o exposto, fácil perceber que o tardio reconhecimento da união entre pessoas do mesmo sexo como entidade familiar mostra-se um avanço crucial para o desenvolvimento de uma sociedade igualitária e evoluída. Realmente não consigo vislumbrar nenhum motivo pertinente para diferenciação dos efeitos jurídicos de uma relação entre homossexuais e heterossexuais, qualquer distinção neste sentido mostra-se uma afronta a nossos princípios constitucionais da igualdade, liberdade e dignidade da pessoa humana.

Neste sentido, me inclino a acreditar que por vezes mais importante do que o reconhecimento dos direitos iguais aos casais homossexuais pelos nossos poderes Judiciário e Legislativo, é a reeducação da sociedade que foi criada por um passado de preconceito, ódio infundado e extremo medo do "novo". Para quem mantém uma mente aberta, não é concebível um debate onde está em jogo a dignidade de um ser humano por questões de preferência sexual, tão absurdo quanto qualquer segregação por raça, cor ou crença. Se todos se concentrassem mais em amar e aceitar o próximo independente de suas diferenças e acima de crenças e pseudo verdades pessoais, talvez o objeto deste trabalho monográfico nem tivesse que ser estudado. Nas palavras do grande poeta, músico e compositor Renato Russo: "É preciso amar as pessoas como se não houvesse amanhã. Porque se você parar para pensar, na verdade não há."77.

\footnotetext{
${ }^{77}$ Música: Pais e Filhos. Autoria: Renato Russo.
} 


\section{Bibliografia}

PEREIRA, Caio Mário da Silva. Instituições de Direito Civil - Volume V Direito de Família. $18^{a}$ ed. Rio de Janeiro: Forense, 2010. 623 p.

DIAS, Maria Berenice. Manual de Direito das Famílias. $6^{a}$ ed. São Paulo: Revista dos Tribunais, 2010.672 p.

ROCHA, Marco Túlio de Carvalho. O conceito de família e suas implicações jurídicas: teoria sociojurídica do direito de família. Rio de Janeiro: Elsevier, 2009, 280 p.

FARIAS, Cristiano Chaves de. Direito constitucional à família (ou famílias sociológicas 'versus' famílias reconhecidas pelo direito: um bosquejo para uma aproximação conceitual à luz da legalidade constitucional). Revista da Escola Superior da Magistratura de Sergipe, $\mathrm{n}^{\circ}$ 03, 2002, $11 \mathrm{p}$.

LÔBO, Paulo, Direito Civil - Famílias, São Paulo: ed. Saraiva, $2^{\mathrm{a}}$ ed., 2009, $411 \mathrm{p}$.

WELTER, Belmiro Pedro, Estatuto da União Estável, $2^{\mathrm{a}}$ Ed. Porto Alegre, 2003, $248 \mathrm{p}$.

ABBAGNANO, Nicola, Dicionário de filosofia. $1^{\mathrm{a}}$ edição brasileira coordenada e revista por Alfredo Bossi, São Paulo: Martins Fontes, 2007, $1.014 \mathrm{p}$.

OLIVEIRA, José Lamartine Corrêa de; MUNIZ, Francisco José Ferreira. Direito de Família. Porto Alegre: Fabris, 1990, 504 p.

PERROT, Michelle. O Nó e o Ninho. Veja: Reflexões para o futuro - 1993, $01 \mathrm{p}$.

LÔBO, Paulo Luiz Netto. Código Civil Comentado: Famílias, $3^{\text {a }}$ Ed. São Paulo: Saraiva, 2010, 370 p.

[19] PEREIRA, Rodrigo da Cunha. Princípio da afetividade. In DIAS, Maria Berenice (coord.). Diversidade sexual e direito homoafetivo. São Paulo: Revista dos Tribunais, 2011, 576 p. 
DIAS, Maria Berenice. União Homoafetiva - O preconceito e a Justiça - $5^{\mathrm{a}}$ ed. Rio de Janeiro: Revista dos Tribunais, 2012, 302 p.

BANDEIRA de MELLO, Celso Antônio. Conteúdo Jurídico do princípio da igualdade. 3 ed. São Paulo: Malheiros, 1999. 48 p.

SARLET, Ingo Wolfgang. Dignidade da Pessoa Humana e Direitos Fundamentais na Constituição Federal de 1988. $3^{\text {a }}$ ed. Porto Alegre: Livraria do Advogado, 2004, 158 p.

DERBLI, Felipe (O papel do Estado membro no controle abstrato de constitucionalidade das leis em matéria de direitos fundamentais. In: VENTURA, Zênio; FAGÚNDEZ, Paulo (Org.). As Perspectivas da Advocacia Pública e a Nova Ordem Econômica. Florianópolis: OAB/SC Editora, 2006, $1593 \mathrm{p}$.

TEPEDINO, Gustavo. (A Disciplina Civil-Constitucional das Relações Familiares. In Temas de Direito Civil. $3^{\text {a }}$ edição. Rio de Janeiro: Renovar, 2004, 483 p.

ALVES, Jones de Figueirêdo - Livro IV - Do Direito de Família. In:, ALLEGRETTI, José Raul (Coord.). O Novo Código Civil, Rio de Janeiro: Tribunal de Justiça do Rio de Janeiro/CEDES Centro de Estudos e Debates - Editora Vozes, 2002, 194 p.

MONTEIRO, Washington de Barros. Curso de Direito Civil - Direito de Família - 32a ed. São Paulo: Saraiva, 1995, 350 p.

RODRIGUES, Silvio - Direito Civil - Direito de Família - Volume 6 - $27^{\mathrm{a}}$ ed. São Paulo: Saraiva, 2002, 476 p.

\section{Jurisprudência}

TJRS, $8^{a}$ Câmara Cível, Apelação Cível nº 70021637145, Rel. Rui Portanova, julgado em 13/12/2007.

STJ, $4^{\mathrm{a}}$ Turma, REsp 820475 RJ 2006/0034525-4, Rel. Ministro Antônio De Pádua Ribeiro, julgado em 02/09/2008.

STJ, $4^{a}$ Turma, REsp 238715 RS 1999/0104282-8, Rel. Ministro Humberto Gomes De Barros, julgado em 06/03/2006. 


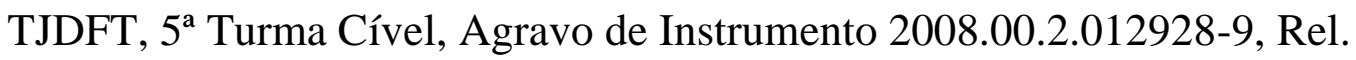
Diva Lucy Ibiapina, julgado em 18/03/2009.

TJRS, $7^{a}$ Câmara Cível, Apelação Cível No 70028838308, Rel. José Conrado Kurtz de Souza, Julgado em 24/06/2009.

TJRJ, $16^{\circ}$ Câmara Cível, Apelação Cível no 0004220-87.2006.8.19.0208 (2007.001.04634), Rel. Marcos Alcino A. Torres, julgado em 24/04/2007.

STF, Ação Direta de Inconstitucionalidade 4.277, Min. Rel. Ayres Britto, julgado em 05/05/2011, p. 11.

STF, Ação Direta de Inconstitucionalidade 4.277, Voto Min. Ricardo Lewandowski, julgado em 05/05/2011, p. 12.

STF, Ação Direta de Inconstitucionalidade 4.277, Voto Min. Gilmar Mendes, julgado em 05/05/2011, p. 51.

STJ, $4^{\mathrm{a}}$ Turma, REsp 1.183.378 - RS (2010/0036663-8), Rel. Ministro Luís Felipe Salomão, julgado em 25/10/2011.

STJ, 4 ${ }^{\mathrm{a}}$ Turma, REsp 1.183.378 - RS (2010/0036663-8), Voto vencido. Ministro Raul Araújo, julgado em 25/10/2011.

STF, Medida Cautelar em Mandado de Segurança 32.077, Min. Rel. Luiz Fux, julgado em 28/05/2013. 


\section{Pontifícia Universidade Católica $_{\text {a }}$ DO RIO DE JANEIRO}

\section{NORMAS PARA ELABORAÇÃO E APRESENTAÇÃO DA MONOGRAFIA JUR 1919 ou JUR 1916}

\section{ANEXO II \\ A Monografia deve ser entregue até o dia 10 de junho de 2013.}

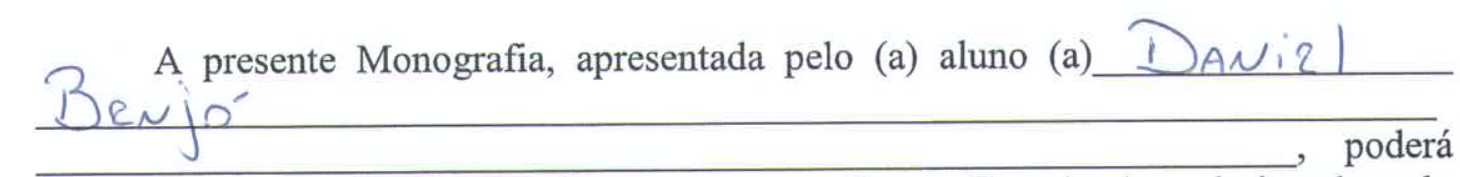

ser submetida à exposição e defesa perante a Banca Examinadora designada pelo Departamento de Direito da PUC-Rio.

Rio de Janeiro, 10 de junho de 2013.

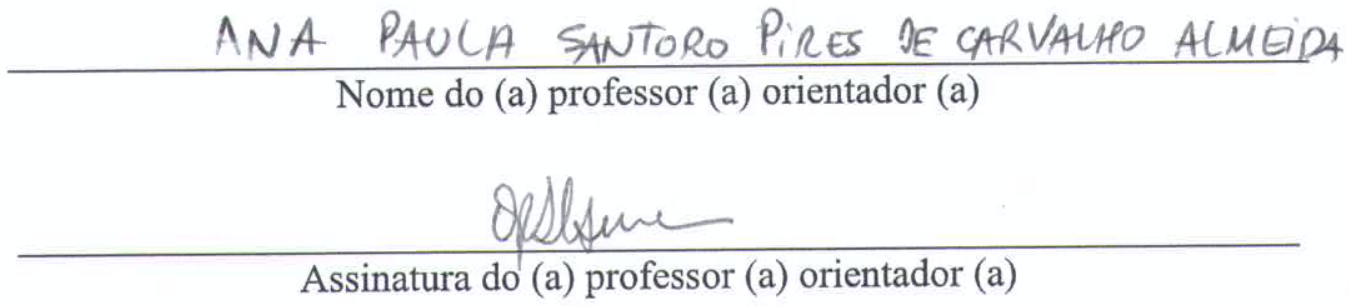

O (A) autor (a) declara para todos os fins de Direito ser este um trabalho inédito de sua autoria e autoriza o Departamento de Direito da PUC-Rio a divulgá-lo, no todo ou em parte, resguardados os direitos autorais conforme legislação vigente.

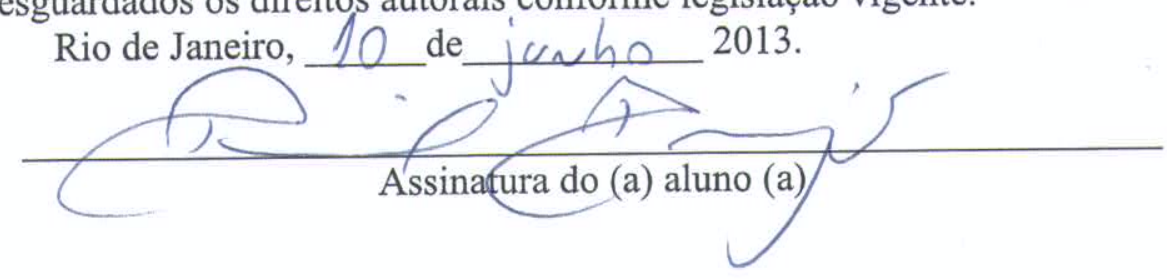

